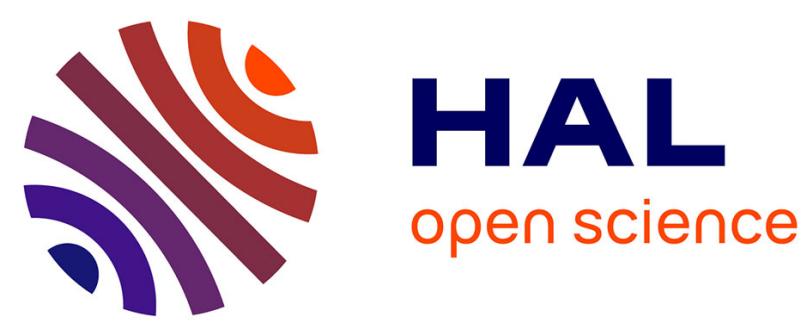

\title{
Trace element bioaccumulation in reef fish from New Caledonia: influence of trophic groups and risk assessment for consumers
}

Marc Metian, Michel Warnau, Tiphaine Chouvelon, Fernando Pedraza, Alessia Rodriguez y Baena, Paco Bustamante

\section{To cite this version:}

Marc Metian, Michel Warnau, Tiphaine Chouvelon, Fernando Pedraza, Alessia Rodriguez y Baena, et al.. Trace element bioaccumulation in reef fish from New Caledonia: influence of trophic groups and risk assessment for consumers. Marine Environmental Research, 2013, 87-88, pp.26-36. 10.1016/j.marenvres.2013.03.001 . hal-00829242

\section{HAL Id: hal-00829242 \\ https://hal.science/hal-00829242}

Submitted on 3 Jun 2013

HAL is a multi-disciplinary open access archive for the deposit and dissemination of scientific research documents, whether they are published or not. The documents may come from teaching and research institutions in France or abroad, or from public or private research centers.
L'archive ouverte pluridisciplinaire HAL, est destinée au dépôt et à la diffusion de documents scientifiques de niveau recherche, publiés ou non, émanant des établissements d'enseignement et de recherche français ou étrangers, des laboratoires publics ou privés. 


\section{Trace element bioaccumulation in reef fish from New Caledonia: influence of trophic groups and risk assessment for consumers}

Marc Metian ${ }^{\mathrm{a}, \mathrm{b}, *}$, Michel Warnau ${ }^{\mathrm{b}}$, Tiphaine Chouvelon ${ }^{\mathrm{a}}$, Fernando Pedraza $^{\mathrm{c}}$, Alessia Rodriguez y Baena ${ }^{\mathrm{d}}$, Paco Bustamante ${ }^{\mathrm{a}}$

${ }^{a}$ Littoral Environnement et Sociétés (LIENSs), UMRi 7266 CNRS-Université La Rochelle, 2 rue Olympe de Gouges, F-17000 La Rochelle, France

${ }^{\mathrm{b}}$ International Atomic Energy Agency - Environment Laboratories (IAEA-EL), 4 Quai Antoine Ier, MC-98000 Principality of Monaco

${ }^{\mathrm{c}}$ Laboratoire des Sciences de l'Ingénieur pour l'Environnement (LASIE), FRE-CNRS 3474 Avenue Michel Crépeau F-17000 La Rochelle, France

${ }^{\mathrm{b}}$ International Atomic Energy Agency - Department of Technical Cooperation (IAEA-TCEU), Wagramerstrasse 5, A-1400 Vienna, Austria

*Corresponding author: $\quad$ Dr. Marc Metian

Stockholm Resilience Center

Stockholm University

SE-106 91 Stockholm, Sweden

Phone: $\quad+46(0) 734611168$

E-mail: marc.metian@ stockholmresilience.su.se 
Abstract: Fourteen trace elements (Ag, As, Cd, Co, Cr, Cu, Fe, Hg, Mn, Ni, Pb, Se, V, and Zn) were analyzed in livers and muscles from 22 fish species from the New Caledonia lagoon, which is subjected to important chemical inputs due to intense land-based mining activities (New Caledonia is the third largest world producer of Ni). The results of this baseline research indicated that livers generally concentrated trace elements to a greater extent than muscles. Nevertheless, the overall trace element concentrations in both tissues were barely above the levels reported in fish and thus contamination at the local scale was poorly discriminated. Although these levels were low, preliminary risk assessment from a global health standpoint suggest that As would be an element potentially leading to exposure of concern for fish consumers. Based on the element concentrations in livers and the fish trophic preferences, some tendencies have been observed among trophic groups: $\mathrm{Ag}, \mathrm{Cu}, \mathrm{Fe}, \mathrm{Hg}$, and $\mathrm{Zn}$ concentrations were generally higher in liver of fish with the highest trophic position whereas $\mathrm{Cd}$ concentrations were lower in these groups. The use of the leopard coral grouper Plectropomus leopardus as a resident top predator allowed determining the geographical variations in contamination levels with significant differences in six out of the fourteen elements investigated. The sampling sites influenced by anthropogenic inputs were revealed by high Ag, $\mathrm{Cd}, \mathrm{Cu}, \mathrm{Hg}$, and $\mathrm{Pb}$ concentrations. Such geographic differences also applied to $\mathrm{Zn}$ but surprisingly not for the typical elements associated with $\mathrm{Ni}$ mining, i.e., $\mathrm{Co}, \mathrm{Cr}, \mathrm{Mn}$ and $\mathrm{Ni}$.

Keywords: Metal; Bioaccumulation; Detoxification; Trophic level; Risk assessment; Tropical environment 


\section{Introduction}

New Caledonia is the third largest producer of nickel (Ni) in the world (Dalvi et al., 2004) and this activity constitutes a threat for the marine environment through metal contamination: it mainly concerns $\mathrm{Ni}$ and its mining by-products such as cobalt $(\mathrm{Co})$, chromium $(\mathrm{Cr})$ and manganese $(\mathrm{Mn})$ which occur at elevated concentrations in Ni ores. However, it has been shown that other metals, such $\mathrm{As}$ or $\mathrm{Hg}$, are also of toxicological concern in this environment (Chouvelon et al., 2009; Hédouin et al., 2009; Metian et al., 2008a).

In this specific context, metal and metalloid bioaccumulation in many taxa such as crustaceans, molluscs, ascidians or marine mammals have been investigated (Bustamante et al., 2000, 2003; Hédouin et al., 2009; Metian et al., 2008a, 2010; Monniot et al., 1994; Pernice et al., 2009), with most of the studies having been dedicated to molluscs, particularly to bivalves (e.g. Hédouin et al., 2009, 2010; Metian et al. 2008a). With the exception of $\mathrm{Hg}$ (Chouvelon et al., 2009), there is a considerable lack of information concerning trace element contamination in fish from New Caledonia.

Given the importance of fish as a staple food in Pacific island countries and territories (PICTs) such as in New Caledonia (an annual per capita fish consumption up to $55 \mathrm{~kg}$ in rural community; Bell et al. 2009), it is also crucial to fill the gap of knowledge concerning metal content in edible fish: a large consumption of fish may lead to an ingestion of a cumulative amount of metals putting local consumers' health at risk.

The main objective of the present study was to provide baseline information on trace element contamination status of the New Caledonia coastal marine environment. For this purpose, a wide range of fish species, collected from different locations previously characterized for their degree of contamination (Chouvelon et al., 2009; Hédouin et al., 2009), were analyzed for their trace element contents. Special emphasis was given to two body compartments: the liver which is involved in the detoxification processes of several trace elements and the muscle which is the 
main part that is eaten, in order to establish a preliminary risk assessment for the consumers. In addition, the variation of element concentrations was investigated in the tissues of the leopard coral grouper Plectropomus leopardus collected in various sites and the variation of element concentrations according to trophic groups was studied for the entire samples set.

\section{Materials and methods}

\subsection{Sampling and sample preparation}

Fish belonging to 22 species were collected in March and October 2007 along the South coast of New Caledonia (Fig. 1, Table 1), either by scuba diving or bought to local fishermen. The sampling sites were selected based on their reported contrasting contamination status (Chouvelon et al., 2009; Hédouin et al., 2009; Metian et al., 2008a): Grande Rade, Koutio Bay, Sainte Marie Bay, Ouano Bay, Maa Bay, Prony Bay (Fig. 1, Table 1). The organisms bought from fishermen were caught in the Southern lagoon (Fig. 1, Table 1).

Due to anthropogenic inputs (industry and extractive metallurgical activities), Grande Rade sediments displayed high concentrations for several trace elements (Hédouin et al., 2009). Koutio Bay is also characterised by an important rubbish dump and is influenced by inputs of domestic wastes from the city of Noumea whereas Sainte Marie Bay receives important sewage sludge from Nouméa and terrigenous inputs from the Coulée River. In contrast, Maa Bay and Ouano Bay located in the Southern Lagoon are preserved from important anthropogenic inputs (Hédouin et al., 2009).

All collected organisms were weighed (wet wt) and measured (total length; up to the base of the caudal fork) upon return to the laboratory. The characteristics (number of individuals, length and weight, sampling period and location) of each of the 22 species collected are given in Table 1. Fish were then dissected in order to collect the liver and a piece of dorsal muscle (standardised cut on dorsal muscle just behind the head). The total number of samples is 124 (details provided 
in Annex 1). Each tissue sample was weighed (wet wt) and immediately placed in individual plastic bags and frozen at $-25^{\circ} \mathrm{C}$. Samples were then freeze-dried and weighed again (dry wt). Freeze-dried tissues were ground and stored in individual plastic vials until further elemental analysis.

Table 1 also indicates the diet habits (through the "trophic group" column) of each species in order to assess, if any, the influence of trophic specificity on bioaccumulation of the studied elements. Diet data have been gathered in Fishbase dataset (Froese and Pauly, 2011) and they are in good agreement with fish diet analyses performed in New Caledonia by Kulbicki et al. (2005). The collected species were arranged into 4 groups in order to observe possible specific range of element concentrations for each trophic group. The groups were the following ones: grazer/scavenger (GS); predator of invertebrates (PI); predator of invertebrates and small fish (PISM); and predator of small fish (PSM). In addition, trophic levels were also gathered in Fishbase dataset (Froese and Pauly, 2011).

\subsection{Trace element analysis}

The analysis of $\mathrm{Ag}, \mathrm{As}, \mathrm{Cd}, \mathrm{Co}, \mathrm{Cr}, \mathrm{Cu}, \mathrm{Fe}, \mathrm{Mn}, \mathrm{Ni}, \mathrm{Pb}, \mathrm{Se}, \mathrm{V}$ and $\mathrm{Zn}$ in the tissues required the mineralization of the samples. Aliquots of liver and muscle ranging from 50 to $300 \mathrm{mg}$ were digested using 3 to $5 \mathrm{ml}$ of a 3:1 (v:v) mixture of $65 \% \mathrm{HNO}_{3}$ and $37 \% \mathrm{HCl}$ (both from Merck and suprapur quality). Acidic mineralization was performed at room temperature overnight, then in a microwave during 30 min with increasing temperature until $105^{\circ} \mathrm{C}$, and $15 \mathrm{~min}$ at $105^{\circ} \mathrm{C}$ $(1200 \mathrm{~W})$. After the mineralization process, each sample was diluted to 30 to $50 \mathrm{ml}$ with milli-Q quality water, according to the volume of acid added to the mineralization. Elements were analyzed using a Varian Vista-Pro ICP-OES (As, Cr, Cu, Fe, Mn, Ni, Se and Zn) or a Varian ICP-MS Ultra Mass 700 (Ag, Cd, Co, Pb and V). 
$\mathrm{Hg}$ was directly analyzed on the dried samples by atomic absorption spectrometry with an Advanced Mercury Analyser (ALTEC AMA 254). Only livers were analyzed since $\mathrm{Hg}$ concentrations in muscles have been reported previously (Chouvelon et al., 2009).

Reference materials (dogfish liver DOLT-4 and lobster hepatopancreas TORT-2; NRCC) were treated and analyzed in the same way as the samples. The results were in good agreement with the certified values, and the relative standard deviations were always below $15 \%$, proving good repeatability of the method. The results for reference materials displayed element recoveries ranging from $72 \%$ to $134 \%$. Blanks were included in each analytical batch. The detection limits ( $\mu \mathrm{g} \mathrm{g}^{-1}$ dry wt) were $0.007(\mathrm{Hg}), 0.03(\mathrm{Ag}, \mathrm{Cd}, \mathrm{Co}), 0.07(\mathrm{~Pb}), 0.67(\mathrm{Cr}, \mathrm{Cu}, \mathrm{Mn}), 1.35(\mathrm{Ni}, \mathrm{V})$, $2.69(\mathrm{Fe}, \mathrm{Zn}), 6.73(\mathrm{As})$, and $13.46(\mathrm{Se})$ for livers and $0.03(\mathrm{Ag}, \mathrm{Cd}, \mathrm{Co}), 0.08(\mathrm{~Pb}), 0.70(\mathrm{Cr}$, $\mathrm{Cu}, \mathrm{Mn}), 1.39(\mathrm{Ni}, \mathrm{V}), 2.78(\mathrm{Fe}, \mathrm{Zn}), 6.96(\mathrm{As})$, and $13.90(\mathrm{Se})$ for muscles. All element concentrations are given on a dry weight basis ( $\mu \mathrm{g} \mathrm{g}^{-1}$ dry wt).

\subsection{Data analysis}

All data submitted to statistical tests were first checked for normality (Shapiro-Wilk test) and for homogeneity of variances (homoscedasticity, Bartlett test). When these conditions were satisfied, parametric tests were used in the subsequent analyses; otherwise, non-parametric analogues were used. Spearman and Pearson correlation coefficient tests were used to analyze the correlations between size or weight and trace element concentration in livers of the leopard coral grouper Plectropomus leopardus (according to the normality and the homoscedasticity of the data). Correlation tests were also used to analyze the correlations between trophic level values of the different species (TL; Froese and Pauly, 2011) and their concentration of metals and metalloids in the liver.

The relationships among all the elements concentrations in fish liver were investigated using a principal component analysis (PCA); the PCA was based on the correlation matrix and 
normalised data for each variable (i.e. centred and divided by the standard deviation). When the major components were determined, projection of the points was realized and relevant characteristics (sampling sites and feeding/trophic groups) were taken into account.

Species/groups of species with a minimum of three individuals/replicates were considered to test differences in trace element concentrations among sampling locations (in the case P. leopardus) or trophic groups, using a one-way analysis of variance (ANOVA) followed by the post-hoc Tukey test. In the case of a correlation between size or weight and trace element concentrations was previously revealed for P. leopardus, ANCOVA was performed instead of ANOVA, using size or weight as co-variable. Normality and homoscedasticity of residuals were also checked. When appropriate, the variability explained by each factor and their interaction was derived from the sum of squares. When required, the Kruskal-Wallis (KW) test was performed as a nonparametric analogue to ANOVA. The KW tests were followed by a multiple comparison test with Holm adjustment method (Chouvelon et al., 2011). The levels of significance for statistical analyses was always set at $\alpha=0.05$.

\subsection{Risk assessment for Human consumers}

A maximum safe consumption of fish was evaluated on the basis of the Provisional Maximum Tolerable Daily Intake (PMTDI) or Provisional Tolerable Weekly Intake (PTWI) given by the Joint Expert Committee on Food Additives (JECFA; http://www.inchem.org/pages/jecfa.html). In this calculation, metal sources supplied by other meals or by drinking water on the same day were not taken into account, i.e. only metal intake coming from the fish has been considered. The PMTDIs for $\mathrm{Cu}, \mathrm{Fe}$, and $\mathrm{Zn}$ are respectively 500, 800 and $1000 \mu \mathrm{g} \mathrm{kg}^{-1} \mathrm{~d}^{-1}$ and PTWI for inorganic As, $\mathrm{Cd}$ and $\mathrm{Pb}$ are 15, 7 and $25 \mu \mathrm{g} \mathrm{kg}{ }^{-1} \mathrm{wk}^{-1}$ (JECFA, 2006; WHO, 1989, 2003). In order to assess a "Maximum Safe Consumption" for $\mathrm{As}, \mathrm{Cd}, \mathrm{Cu}, \mathrm{Pb}, \mathrm{Zn}$ and $\mathrm{Fe}$ (per week or day, depending of the studied element: PMTDI or PTWI), mean concentrations in $\mu \mathrm{g} \mathrm{g}^{-1}$ dry wt 
measured for each muscle sample were first converted to wet wt, taking into account a conventional dry wt/wet wt ratios (75\%; Chouvelon et al. 2009). Then, the respective PMTDI or PTWI multiplied by a consumer average body weight (viz. 50 and $80 \mathrm{~kg}$ for female and male humans, respectively) was divided by the element concentration in the considered fish muscle to obtain the "Maximum Safe Consumption" (g wet wt). It can be summarized with the following equation (Equ. (1)):

$\mathrm{MSC}_{\mathrm{A}}=\left(\mathbf{W}_{\text {ind }} * \mathrm{JL}_{\mathbf{A}}\right) / \mathbf{X}_{\mathrm{A}}$

Where $\mathbf{M S C}_{\mathbf{A}}$ is the Maximum Safe Consumption of a food item in relation with a contaminant $\mathrm{A}, \mathbf{X}_{\mathbf{A}}$ is mean concentrations in $\mu \mathrm{g} \mathrm{g}^{-1}$ wet wt converted to mean concentrations in $\mu \mathrm{g} \mathrm{g}^{-1}$ dry wt, $\mathbf{W}_{\text {ind }}$ is body weight $(\mathrm{kg})$ of the human for whom the assessment of the $\mathrm{MSC}_{\mathrm{A}}$ is carried out. $\mathbf{J L}_{\mathbf{A}}$ represents either PTWI or PMTDI of A. $\mathrm{MSC}_{\mathrm{A}}$ will thus provide a mass of fish that will represent the maximum amount allowed per day or per week (depending on whether PMTDI or PTWI were used).

\section{Results}

\subsection{Tissue concentrations}

The trace element concentrations in the liver of the different fish species collected from the different sampling sites are given in Table 2. The ranges of concentrations for each element

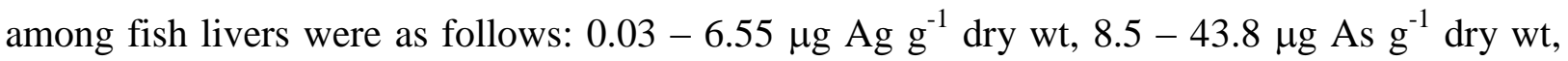
$0.06-16.7 \mu \mathrm{g} \mathrm{Cd} \mathrm{g}^{-1}$ dry wt, $0.13-6.67 \mu \mathrm{g} \mathrm{Co} \mathrm{g}{ }^{-1}$ dry wt, $0.78-5.33 \mu \mathrm{g} \mathrm{Cr} \mathrm{g}^{-1}$ dry wt, $1.11-$ $642 \mu \mathrm{g} \mathrm{Cu} \mathrm{g}{ }^{-1}$ dry wt, 240 - $8766 \mu \mathrm{g} \mathrm{Fe} \mathrm{g}^{-1}$ dry wt, $0.03-6.44 \mu \mathrm{g} \mathrm{Hg} \mathrm{g}{ }^{-1}$ dry wt, $0.93-8.77 \mu \mathrm{g}$ $\mathrm{Mn} \mathrm{g}^{-1}$ dry wt, $1.47-5.02 \mu \mathrm{g} \mathrm{Ni} \mathrm{g}{ }^{-1}$ dry wt, $0.06-1.82 \mu \mathrm{g} \mathrm{Pb} \mathrm{g}{ }^{-1}$ dry wt, $16.2-21.3 \mu \mathrm{g} \mathrm{Se} \mathrm{g}{ }^{-1}$ dry wt, $1.20-8.36 \mu \mathrm{g} \mathrm{V} \mathrm{g}^{-1}$ dry wt, and $19.6-1662 \mu \mathrm{g} \mathrm{Zn} \mathrm{g}^{-1}$ dry wt. 
Concentrations of trace elements in fish muscle are presented in Table 3. This table does not contain data for $\mathrm{Ag}, \mathrm{Cd}$ and $\mathrm{Ni}$ (which concentrations were always below the detection limits of the analytical method) nor for Se (which was above the detection limit only in the muscle of Epinephelus maculates in Ouano: $\left.21.3 \mu \mathrm{g} \mathrm{g}^{-1} \mathrm{dry} \mathrm{wt} ; \mathrm{n}=1\right)$. The ranges of concentrations for the other elements (As, $\mathrm{Co}, \mathrm{Cr}, \mathrm{Cu}, \mathrm{Fe}, \mathrm{Mn}, \mathrm{Pb}, \mathrm{V}$, and $\mathrm{Zn}$ ) in the fish muscles were: $6.83-38.4 \mu \mathrm{g}$ As g ${ }^{-1}$ dry wt, $0.02-0.35 \mu \mathrm{g} \mathrm{Co} \mathrm{g}^{-1}$ dry wt, $0.88-1.38 \mu \mathrm{g} \mathrm{Cr} \mathrm{g}^{-1}$ dry wt, $0.46-1.51 \mu \mathrm{g} \mathrm{Cu} \mathrm{g}^{-1}$ dry wt, $5.38-37.1 \mathrm{Fe} \mathrm{g}^{-1}$ dry wt, $0.23-1.06 \mu \mathrm{g} \mathrm{Mn} \mathrm{g}{ }^{-1}$ dry wt, $0.09-0.15 \mu \mathrm{g} \mathrm{Pb} \mathrm{g}^{-1}$ dry wt, and $8.59-38.2 \mu \mathrm{g} \mathrm{Zn} \mathrm{g}{ }^{-1}$ dry wt.

When data was available in both livers and muscles, the liver to muscle ratio was calculated. This ratio was over 1 in most cases and reached up to 742 for $\mathrm{Fe}$ in Cymbacephalus beauforti from Prony Bay. The only few exceptions to this "enrichment" factor were found for As in Haemulidae species $(0.52,0.82,0.76$ in Plectorhinchus albovittatus, P. chaetodonoides, P. flavomaculatus, respectively) and for $\mathrm{Pb}(0.82)$ in the Sparidae Acanthopagrus berda from Ouano Bay.

The trace element concentrations in fish livers were combined in a PCA (Fig. 2). The first two principal components accounted for $44 \%$ of the total variation present in the data set $(24 \%$ and $20 \%$ for axes 1 and 2, respectively). Co, Fe, Mn, V, and $\mathrm{Zn}$ concentrations were the variables contributing the most to the first axis (contribution of each variable $>10 \%$ ), whereas $\mathrm{Ag}, \mathrm{Cu}$, $\mathrm{Ni}, \mathrm{Pb}, \mathrm{Zn}$, and $\mathrm{Se}$ concentrations mostly contributed to the second one (contribution of each variable >10\%). The major components 1 and 2 showed that liver $\mathrm{Cd}$ concentrations were highly correlated to $\mathrm{Cr}$ concentrations (Fig. 2A) and negatively correlated to $\mathrm{Ag}, \mathrm{Cu}$ and $\mathrm{Zn}$ concentrations. When individuals were grouped by locations or by trophic groups (Figs $2 \mathrm{C}$ and 2D), no clear segregation emerged from the PCA. Nevertheless, Sainte-Marie Bay and predators of small fish (PSM) seem to be related to elevated concentrations of $\mathrm{Ag}, \mathrm{Cu}$ and $\mathrm{Zn}$. 


\subsection{Element concentrations among sampling locations}

Figure 3 displays the concentrations of trace elements in the liver of the leopard coral grouper $P$. leopardus from different sites of the lagoon of New Caledonia. A significant, positive correlation was found between $\mathrm{Ag}, \mathrm{Cd}, \mathrm{Co}, \mathrm{Cu}, \mathrm{Hg}$ and $\mathrm{Ni}$ concentrations and fish size or weight. The appropriate factor (weight for $\mathrm{Ag}, \mathrm{Cu}$ and $\mathrm{Ni}$; size for $\mathrm{Cd}, \mathrm{Co}$ and $\mathrm{Hg}$ ) was then used as covariable in the ANCOVA performed to test the differences among sites when normality and homogeneity of variances was verified.

$\mathrm{Ag}, \mathrm{Cd} \mathrm{Cu}, \mathrm{Hg}, \mathrm{Pb}$ and $\mathrm{Zn}$ concentrations in the liver displayed significant differences among sampling sites ( $\mathrm{p}_{\mathrm{ANCOVA}}$ or $\mathrm{p}_{\text {Krustal-Wallis }}$ or $\mathrm{p}_{\mathrm{ANOVA}}<0.0001$ for $\mathrm{Ag}, \mathrm{Cu}$ and $\mathrm{Pb} ;<0.05$ for $\mathrm{Hg}, \mathrm{Cd}$ and $\mathrm{Zn}$ ). Multiple comparison tests (or Post hoc Tukey test) also showed that the highest trace element concentrations were not always measured in the liver of fish from the same location. For example, the Ag concentrations in the liver of the leopard coral grouper P. leopardus were significantly higher in Sainte-Marie and Koutio Bays whereas the highest $\mathrm{Pb}$ concentrations were found in Grande Rade. Nevertheless, the highest mean values of liver concentrations were found in Grande Rade for seven out of the fourteen elements examined (i.e., $\mathrm{As}, \mathrm{Co}, \mathrm{Hg}, \mathrm{Mn}$, $\mathrm{Pb}, \mathrm{Se}$, and $\mathrm{V}$ ) whereas the lowest mean concentrations of $\mathrm{Fe}$ and $\mathrm{Zn}$ were found in fish from this site. Relatively homogeneous concentrations of trace elements related to $\mathrm{Ni}$ mining ores (Co, Cr, Mn and Ni) were found in P. leopardus livers collected from the different sampling locations.

\subsection{Element concentrations and trophic positions}

Figure 4 depicts the trace element concentrations in liver by groups through bar plots (mean \pm standard deviation). Regardless of the site, liver concentrations of most elements (i.e., Ag, As, $\mathrm{Cd}, \mathrm{Cr}, \mathrm{Cu}, \mathrm{Fe}, \mathrm{Hg}, \mathrm{Mn}, \mathrm{Ni}, \mathrm{Se}$ and $\mathrm{Zn}$ ) displayed significant differences among trophic groups (Kruskal-Wallis rank sum test $<0.001$ for $\mathrm{Ag}, \mathrm{Cd}, \mathrm{Cu}, \mathrm{Zn}$; Kruskal-Wallis rank sum test $<0.01$ 
for As, $\mathrm{Cr}, \mathrm{Fe}, \mathrm{Hg}, \mathrm{Ni}, \mathrm{Se}$; ANOVA <0.001 for Mn). A multiple comparison test also showed that top predator group (PSM) showed the highest concentrations of $\mathrm{Ag}$ and $\mathrm{Cu}$ (Fig. 4). In addition, liver $\mathrm{Zn}$ concentrations also increased with higher trophic position although this trend was not significant for all the selected groups. Similarly, Fe and $\mathrm{Hg}$ concentrations in PSM groups were the highest (significantly higher than GS for Fe and GS and PISM for $\mathrm{Hg}$ ). However, the group of predators of invertebrates (PI) had relatively high concentrations for both metals.

In contrast, $\mathrm{Cd}$ concentrations showed a significant decrease with increasing trophic position. The highest liver concentrations of $\mathrm{Mn}$ and $\mathrm{Ni}$ were found in the group of predator of invertebrates and small fish (PISM) and the group of predator of invertebrates (PI) displayed greater liver concentrations of As and Se than the other groups.

Significant correlation $(\mathrm{p}<0.05)$ between liver element concentrations and trophic level values (TL; determined by Froese and Pauly, 2011) was observed for all elements except $\mathrm{Mn}, \mathrm{Pb}$ and $\mathrm{V}$. With the increase of TL a significant increase of the concentrations of $\mathrm{Ag}(\mathrm{r}=0.66), \mathrm{Cu}$ (0.62), $\mathrm{Fe}$ (0.47), $\mathrm{Hg}(0.46)$ and $\mathrm{Zn}$ (0.59) was observed and confirmed the higher concentrations of these metals also displayed in top predator group (PSM). In contrast, concentrations of $\mathrm{Cd}, \mathrm{Co}, \mathrm{Cr}, \mathrm{Ni}$ and Se decreased with the increase of TL ( $\mathrm{r}=-0.44,-0.34$, $0.40,-0.41$ and -0.33 , respectively).

\subsection{Risk assessment for Human consumers}

The Maximum Safe Consumption (MSC) of fish was calculated based on the mean concentration of element in edible flesh (viz. muscle) of each species per site. MSC can be calculated on a daily basis or on weekly basis and it depends on the recommended intake for each contaminant by JECFA (WHO, 2003): either PTWI or PMTDI. 
The "Maximum Safe Daily Consumption" (MSDC, in kg wet wt) of edible flesh for $\mathrm{Cu}, \mathrm{Fe}$ and Zn was above $0.8 \mathrm{~kg}$ for a $50-\mathrm{kg}$ person $(12.4 \mathrm{~kg}, 0.81 \mathrm{~kg}$ and $0.98 \mathrm{~kg}$, respectively) and above $1.2 \mathrm{~kg}$ for an $80-\mathrm{kg}$ person $(19.9 \mathrm{~kg}, 1.29 \mathrm{~kg}$ and $1.57 \mathrm{~kg}$, respectively). However, the consumption of Moontail bullseye (Priacanthus hamrur) should be limited since the calculated MSDC for Zn was $133 \mathrm{~g}$ for a 50-kg person and $213 \mathrm{~g}$ for an $80-\mathrm{kg}$ person.

The "Maximum Safe Weekly Consumption" (MSWC, in kg wet wt) of edible flesh for inorganic $\mathrm{As}$ and $\mathrm{Pb}$ values was estimated taking into account the "Provisional Tolerable Weekly Intake’" (PTWI) recommended by JECFA (WHO, 2003). The maximum amount of fish that should be eaten by a $50-\mathrm{kg}$ person to reach the PTWI for $\mathrm{Pb}$ is about $6.25 \mathrm{~kg}$ over a week (ca. $10 \mathrm{~kg}$ for an $80-\mathrm{kg}$ person). Overall, As appears as the only element of concern regarding the consumption of New Caledonian fish: its MSWC for a 50-kg person is ranging between 14.6 and $82.4 \mathrm{~g}$ (23.4 - $132 \mathrm{~g}$ for an 80-kg person). The consumption of Bodianus perditio, Plectorhinchus albovittatus, $P$. chaetodonoides and P. flavomaculatus should be limited the most (max ca. 14 to $30 \mathrm{~g}$ for $50-\mathrm{kg}$ persons and ca. 23 to $50 \mathrm{~g}$ for $80-\mathrm{kg}$ persons).

\section{Discussion}

\subsection{Tissue-specific trace element concentrations and related risk for consumers}

Most studies carried out so far on metal bioconcentration in the New Caledonia waters have investigated macroalgae, invertebrates (crustaceans, molluscs, and ascidians) and marine mammals (Bustamante et al., 2000, 2003; Hédouin et al., 2009; Metian et al., 2008a, 2008b; Metian \& Warnau, 2008; Moniot et al., 1994; Pernice et al., 2009) whereas only one study focussed on fish in which muscular concentrations of $\mathrm{Hg}$ were examined (Chouvelon et al., 2009). In this respect, the dataset of the present study provides substantial baseline information on trace element contamination status of fish from the New Caledonia lagoon. Our dataset is also a good tool to assess the risk related to local fish consumption in a tropical lagoon subjected 
to high metal inputs (Ambastian et al., 1997). In general, trace element concentrations measured in edible tissues (viz. muscles) did not reveal excessive risk for consumers in New Caledonia. Nevertheless, As and to a very lesser extend $\mathrm{Zn}$ (only for the consumption of the Moontail bullseye Priacanthus hamrur) might pose some hazard for human consumers. However these data are probably somewhat overestimated as one has to keep in mind that only 10 out of 22 species were concentrating measurable levels of total As and that the MSWC calculation is based on a $100 \%$ proportion of inorganic As which is not the case in fish (EFSA, 2009).

To better assess the extent of this risk, speciation of As in fish flesh should be investigated as it may be mainly under organic forms, which are generally assumed to be of no toxicological concern (EFSA, 2009). The latter subject is however a matter of debate as many organoarsenicals undergo biotransformation, and consumers can therefore be exposed to their toxic intermediates (Buchet et al., 1996; Le et al., 1994; Moore et al., 1994). In seafood, it is generally considered that approximately $10 \%$ of the total As is under inorganic form (Tao and Bolger, 1998). Hence, when applying a factor of 10 to our risk assessment computation, As concentration found in some species of fish (e.g. P. flavomaculatus) might still be a health risk for the consumers since their MSWC (week dose) for a $50 \mathrm{~kg}$ person would still range between realistic values of 141 and $823 \mathrm{~g}(230 \mathrm{~g}-1.3 \mathrm{~kg}$ for a $80 \mathrm{~kg}$ person). Muscles of New Caledonian fish displayed generally low concentrations of trace elements, whether they came from locations impacted or not by mining activities. The comparison with the data available in the literature indicated that trace element concentrations found in the muscle of New Caledonian fish were generally similar or, in most cases, lower than the values reported for fish from other tropical regions (e.g., Eisler, 2010; Neff, 2000). Only As displayed similar or slightly higher levels than average concentrations in muscle of comparable tropical fish. Indeed, the concentrations of this metalloid measured during the present study ranged from 6.8 to $38 \mu \mathrm{g} \mathrm{g}^{-1}$ dry wt corresponding to 1.4 to $7.7 \mu \mathrm{g} \mathrm{g}^{-1}$ wet wt whereas its range in fish muscle is generally 
from 2 to $5 \mu \mathrm{g} \mathrm{g}^{-1}$ wet wt (Eisler, 1981). However, high As concentrations have already been reported in fish muscles, reaching up to 52.3 and $77.6 \mu \mathrm{g} \mathrm{g}^{-1}$ dry wt, respectively in Hippoglossoides elassodon and in Parupeneus multifasciatus (Denton et al., 2006; Meador et al., 1998). Eisler (2010) noted that As muscular concentrations were generally lower than liver ones. Our data are generally in agreement with this observation. Nevertheless, the As liver/muscle concentration ratio was equal to $0.52,0.82,0.76$ in Plectorhinchus albovittatus, $P$. chaetodonoides, P. flavomaculatus, respectively (all belonging to the Haemulidae Family). To our knowledge such ratios below 1 have never been highlighted although examination of the literature data regarding fish from both pristine and contaminated areas reveals that As concentrations higher in the muscles than in the liver have already been reported (Denton et al., 2006; Meador et al., 2004). This preferential accumulation of As in fish muscles is not well understood and therefore deserves additional investigations.

The liver, which may be the largest organ after the muscles in a fish body, is not directly involved in digestion, but assimilates nutrients, produces bile, and detoxifies toxins from both endogenous (metabolic) and exogenous sources (Bone and Moore, 2008). With the exception of As, the liver accumulates higher concentrations of trace elements than muscle in fish from New Caledonia, (Tables 1 and 2). This observation is consistent with data previously reported (Eisler, 2010; Neff, 2002) and likely results from the detoxification processes occurring in the liver to cope with the potential toxicity of trace elements. The resulting bioaccumulation also closely relates to the metabolism of essential elements in fish, which leads to their storage and mobilization for vital requirements.

Although many studies have been conducted on trace elements in fish, some elements such as $\mathrm{Co}, \mathrm{Cr}, \mathrm{Mn}, \mathrm{Ni}, \mathrm{Se}$, and V have rarely been investigated (Eisler, 2010). These elements were analyzed in the present study to generate a baseline dataset for various tropical fish species. In addition, $\mathrm{Co}, \mathrm{Cr}, \mathrm{Mn}$ and $\mathrm{Ni}$ are closely related to the mining activities occurring in New 
Caledonia and can be of concern to fish from the New Caledonia lagoon and to their consumers. As opposed to the low concentrations of these elements in muscle, their content is relatively high in liver, thereby confirming the role of the latter organ in the detoxification and storage of these trace elements as well. Overall, the range of liver $\mathrm{Co}, \mathrm{Cr}, \mathrm{Mn}$ and $\mathrm{V}$ concentrations was similar to the values generally reported in fish (Table 4). Ni concentrations were somewhat higher than those reported for tropical fish, which is in agreement with the fact that Ni concentrations in fish tissues are frequently elevated in the vicinity of $\mathrm{Ni}$ smelters and refineries, Ni-Cd battery plants, sewage outfalls, and coal ash disposal basins (Eisler, 2010). Nevertheless, Ni was accumulated significantly in the liver only by few species (several species remained under the detection limit), with the highest Ni level measured in P. chaetodonoides from Grande Rade subjected to important releases of Ni mining products and by-products (e.g. Hédouin et al., 2009).

Although $\mathrm{Cu}$ is less accumulated in fish than in algae or invertebrates (Eisler, 2010), high levels were reported in fish from tropical areas (Eisler, 2010) and the range of liver $\mathrm{Cu}$ concentrations (e.g. 1.61-319 $\mu \mathrm{g} \mathrm{g}^{-1}$ dry wt in Guam harbors fish; Denton et al., 2006) is wider and higher than in fish from temperate areas (Eisler, 2010). The range of $\mathrm{Cu}$ concentrations in New Caledonia fish is even wider and maximum value is higher $\left(1.11-642 \mu \mathrm{g} \mathrm{g}^{-1}\right.$ dry wt) than previously reported in Guam harbors fish.

$\mathrm{Zn}$ is an essential element that is also well studied in fish (e.g. Bury et al., 2003) and tends to be highly bioaccumulated in liver of some New Caledonian fish (up to $1662 \mu \mathrm{g} \mathrm{Zn} \mathrm{g}^{-1}$ dry wt). Our results showed however considerable inter- and intra- specific variability with values ranging between 20 and $1662 \mu \mathrm{g} \mathrm{Zn} \mathrm{g}{ }^{-1}$ dry wt. These results are consistent with previously reported liver concentrations of $\mathrm{Zn}$ for other tropical fish, ranging between 12 and $2284 \mu \mathrm{g} \mathrm{Zn} \mathrm{g}{ }^{-1}$ dry wt (Denton and Burdon-Jones, 1986; Denton et al., 2006). 


\subsection{Variation of trace element concentrations among sampling sites}

In order to evaluate the bioavailability of metals along the New Caledonian coast, bivalves have been previously used (Hédouin et al., 2009). However, fish can also be good bioindicators considering their biological and life cycle specificities. For instance, the restricted mobility of fish species (characterizing thus a limited living area) is a suitable characteristic for a marine fish providing a site-specific record of the contamination; it fulfils one of the general prerequisite of bioindicator species (Phillips and Rainbow, 1994). Here, we considered the leopard coral grouper $P$. leopardus as a potential bioindicator species in order to compare different locations as this fish is resident in its living area and is an apex predator (St. John, 1999; Zeller, 1997). To this end, the liver was used to establish the comparisons as it has been shown as the target organ for most of the trace elements examined (Table 2). Coral groupers caught in Koutio and Sainte-Marie Bays showed the highest $\mathrm{Ag}$ and $\mathrm{Cu}$ concentrations among sampling sites. Koutio Bay is influenced by the inputs of domestic wastes from Noumea City and by the occurrence of an important rubbish dump. Sainte-Marie Bay receives urban wastewaters from the Sainte-Marie area (district of Nouméa). For Ag, results on leopard coral groupers are in agreement with previous works on algae and invertebrates collected in urban areas such as Sainte-Marie bay (Hédouin et al., 2009; Metian et al., 2008a). On the other hand, the liver of $P$. leopardus did not show significant differences among sites for metals related to the mining activities (viz. Co, Cr, Mn, Ni). This result deserves particular attention as in Grande Rade, that is subjected to important inputs of mining products and by-products as confirmed by recent sediment analyses (Hédouin et al., 2009), invertebrates showed clearly higher Co, Cr and Ni concentrations compared to the other stations (Hédouin et al., 2011b). In contrast, our observations suggest that these metals are not readily bioavailable for fish from the dissolved phase and/or that they are poorly transferred through the food chain up to leopard coral groupers. Similarly limited contaminations by trace metals have been previously observed in 
tissues of fish exposed to mine waste disposal (Brewer et al., 1997). Among the trace elements considered, only $\mathrm{Hg}$ and $\mathrm{Pb}$ were significantly more bioaccumulated in fish from Grande Rade than from the other sampling stations, likely resulting from the releases from human activities in this site. In contrast to the other metals, Cd was significantly higher in Ouano, Maa and Sainte Marie Bays than in the other sites (Fig. 3). As it was for mining-related elemenst, these observations are not in accordance with Cd contamination status of sediment (Hédouin et al., 2009), which confirms the importance to work directly on the organism in order to better estimate the biological significance of reported contamination levels.

\subsection{Variation of element concentrations according to trophic groups}

Diet is generally considered as the major route for trace element bioaccumulation in fish (Willis and Sunda, 1984; Xu and Wang, 2002; Zhang and Wang, 2006). Bioavailability of metals from ingested food is strongly influenced by the nature of the food and varies considerably among species (e.g. Luoma et al., 2002). The present study revealed a strong relationship between the concentrations of several elements ( $\mathrm{Ag}, \mathrm{As}, \mathrm{Cu}, \mathrm{Cd}, \mathrm{Hg}, \mathrm{Mn}, \mathrm{Se}$ and $\mathrm{Zn}$ ) in storage tissues and the fish feeding preferences/regimes. The best example was $\mathrm{Zn}$ for which liver concentrations increased with both trophic level and trophic groups (Fig. 4). However, this positive relationship is contrasting with the results of Ting (1971) who did not find any significant difference in the content of $\mathrm{Zn}$ in the muscle, skin, viscera, or bones of 7 species of fish representing various feeding regimes. Moreover an inverse relationship between $\mathrm{Zn}$ concentrations and trophic position has even been suggested in some earlier studies on global food webs (Schafer et al., 1982; Young and Mearns, 1979; Young et al., 1980). Therefore, these controversial observations deserve further attention and research.

As for $\mathrm{Zn}$, the liver concentrations of $\mathrm{Ag}$ and $\mathrm{Cu}$ were generally higher in high trophic level fish. The highest liver concentrations of $\mathrm{Cu}$ were displayed by the leopard coral grouper $P$. 
leopardus, which also exhibited high concentrations of $\mathrm{Ag}, \mathrm{Hg}$, and $\mathrm{Zn}$ (Table 2). These observations are probably related to the induction of metallothionein-like proteins that have a high affinity for these elements (Hamilton and Mehrle, 1986).

The behaviour of $\mathrm{Cd}$ and to a lesser extent of $\mathrm{Cr}$, tended to be opposite to $\mathrm{Ag}, \mathrm{Cu}$ and $\mathrm{Zn}$ in fish liver in terms of variation of concentrations among trophic groups defined in the present study (Figs. 2 and 3). Indeed, the liver Cd concentration was the lowest in the highest trophic group $\left(\mathrm{PSM}=0.72 \pm 1.18 \mu \mathrm{g} \mathrm{g}^{-1} \mathrm{dwt}\right)$ and the highest in grazers/scavengers $\left(5.37 \pm 4.10 \mu \mathrm{g} \mathrm{g}^{-1} \mathrm{dwt}\right)$ Even though the considerable inter-specific variability observed previously (Denton and Burdon-Jones, 1986) and in the present study (Table 1) prevents concluding that liver Cd concentrations are decreasing with the increasing trophic level of fish, the trend is supported by the variation of $\mathrm{Cd}$ concentrations along with the variation in food regime (TL in function of $\mathrm{Cd}$ concentrations; Froese and Pauly, 2011) and further research on this subject is needed.

Intermediate feeding regimes (omnivorous or PI and PISM groups) tended to display significantly high levels of As, Mn and Se. PI and PISM fish with elevated As concentrations in their tissues (Fig. 3) usually came from sites where As concentrations in invertebrates were relatively high too (Hédouin et al., 2009). Previous studies carried out in New Caledonia have shown the capacity of invertebrates to highly accumulate As in their tissues (Metian et al., 2008a; Hédouin et al., 2009). For example, very high As concentrations were found in the clam Gafrarium tumidum from Ouano Beach $\left(441 \pm 84 \mu \mathrm{g} \mathrm{g}^{-1}\right.$ dry wt; Hédouin et al., 2009). These observations are further confirming the importance of the dietary route for As uptake (Meador et al., 2004).

In the case of Mn, liver concentrations were systematically higher in the trophic group "PISM" than in other groups, confirming the importance of food pathway for the accumulation of this element (Eisler, 2010). Nevertheless, further investigations and a larger sampling set are 
required to explain the reasons why this group consuming invertebrates and small fish accumulated more Mn than groups eating exclusively invertebrates or fish.

\section{Conclusion}

The present paper indicated that metal concentrations in fish tissues does not clearly reflect the specific contaminated environment where they live in the context of Ni mining activity in New Caledonia. Some metals such as $\mathrm{Ag}, \mathrm{Cd}, \mathrm{Cu}, \mathrm{Hg}$ and $\mathrm{Zn}$ are nevertheless differentially bioaccumulated in fish in different locations demonstrating the potential ability of $P$. leopardus to be used as bioindicator species to evaluate the contamination status of its environment, especially the urban disturbances. Food preferences seem to play a key role in the accumulation of several trace elements ( $\mathrm{Ag}, \mathrm{As}, \mathrm{Cd}, \mathrm{Cu}, \mathrm{Mn}$ and $\mathrm{Zn}$ ) in fish from New Caledonia. Dedicated investigations should be carried out on this issue in future field studies to complement laboratories studies of trace element bioaccumulation in fish. Finally, risk of potential As poisoning through the consumption of fish should be further assessed through specific determination of the inorganic As content in fish tissues.

\section{Acknowledgments}

The authors are grateful to O. Pringault (IRD-Nouméa) for his help in organising the fieldwork, to Captain M. Clarque (IRD-Nouméa), the IRD Diver Team for providing access to their diving equipment and to C. Churlaud (LIENSs) for the trace element analyses. MW is an Honorary Senior Research Associate of the National Fund for Scientific Research (NFSR, Belgium). The IAEA is grateful for the support provided to its Environment Laboratories by the Government of the Principality of Monaco. This work was supported by the IAEA, the University of La Rochelle, the PNEC Programme (Chantier Nouvelle-Calédonie) and the IRD. 


\section{References}

Ambastian, P., Fernex, F., Bernat, M., Parron, C., Lecolle, J., 1997. High metal inputs to closed seas: the New Caledonia lagoon. Journal of Geochemical Exploration 59, 59-74.

Bell, J.D., Kronen, M., Vunisea, A., Nash, W.J., Keeble, G., Demmke, A., Pontifex, S., Andréfouët, S., 2009. Planning the use of fish for food security in the Pacific. Marine Policy 33, 64-76.

Bone, Q., Moore, R.H., 2008. Biology of fishes, third ed. Taylor \& Francis Group, New York.

Brewer, D.T., Milton, D.A., Fry, G.C., Dennis, D.M., Heales, D.S., Venables, W.N., 2007. Impacts of gold mine waste disposal on deepwater fish in a pristine tropical marine system. Marine Pollution Bulletin 54 (3), 309-321.

Buchet, J.P., Lison, D., Ruggeri, M., Foa, V., Elia, G., 1996. Assessment of exposure to inorganic arsenic, a human carcinogen, due to the consumption of seafood. Archives of Toxicology 70, 773778.

Burdon-Jones, C., Denton, G. RI W., Jones, G. B. \& McPhie, K. A., 1975. Metals in marine organisms, Part 1. baseline survey, Progress Report to the Water Qual. Council, Dept. Local Govt., Queensland

Bury, N.R., Walker, P.A., Glover, C.N., 2003. Nutritive metal uptake in teleost fish. Journal of Experimental Biology 206, 11-23.

Bustamante, P., Garrigue, C., Breau, L., Caurant, F., Dabin, W., Greaves, J., Dodemont, R., 2003. Trace elements in two odontocete species (Kogia breviceps and Globicephala macrorhynchus) stranded in New Caledonia (South Pacific). Environmental Pollution 124, 263-271.

Bustamante, P., Grigioni, S., Boucher-Rodoni, R., Caurant, F., Miramand, P., 2000. Bioaccumulation of 12 trace elements in the tissues of the nautilus Nautilus macromphalus from New Caledonia. Marine Pollution Bulletin 40, 688-696.

Chouvelon, T., Warnau, M., Churlaud, C., Bustamante, P., 2009. Hg concentrations and related risk assessment in coral reef crustaceans, molluscs and fish from New Caledonia. Environmental Pollution 157(1), 331-340.

Chouvelon, T., Spitz, J., Cherel, Y., Caurant, F., Sirmel, R., Mèndez-Fernandez, P., Bustamante, P., 2011. Inter-specific and ontogenic differences in $\delta^{13} \mathrm{C}$ and $\delta^{15} \mathrm{~N}$ values and $\mathrm{Hg}$ and $\mathrm{Cd}$ concentrations in cephalopods. Marine Ecology Progress Series 433, 107-120.

Dalvi, A.D., Bacon, W.G., Osborne, R.C., 2004. The past and the future of nickel laterites. PDAC 2004 International Convention, Trade Show \& Investors Exchange, Toronto.

Denton, G.R.W., Burdon-Jones, C., 1986. Trace metals in fish from the Great Barrier Reef. Marine Pollution Bulletin 17(5), 201-209.

Denton, G.R.W., Concepcion, L.P., Wood, H.R., Morrison, R.J., 2006. Trace metals in marine organisms from four harbours in Guam. Marine Pollution Bulletin 52(12), 1784-1804.

EFSA, 2009. EFSA Panel on Contaminants in the Food Chain (CONTAM); Scientific Opinion on Arsenic in Food. EFSA Journal 7(10), 1351. 
Available at http://www.efsa.europa.eu/en/scdocs/scdoc/1351.htm (accessed January 14, 2010).

Eisler, R., 1981. Trace metal concentrations in marine organisms. Pergamon Press, New York.

Eisler, R., 2010. Chapter 3: Fishes. In: Eisler, R., Compendium of trace metals and marine biota: Volume 2: Vertebrates. Elsevier Science, New York, pp. 39-221.

Froese, R., Pauly, D., 2011. FishBase. World Wide Web electronic publication. www.fishbase.org., version $(06 / 2011)$.

Hamilton, S.J., Mehrle, P.M., 1986. Metallothionein in Fish: Review of its importance in assessing stress from metal contaminants. Transactions of the American Fisheries Society 115 (4), 596-609.

Hédouin, L., Bustamante, P., Churlaud, C., Pringault, O., Fichez, R., Warnau, M., 2009. Trends in concentrations of selected metalloid and metals in two bivalves from the SW lagoon of New Caledonia. Ecotoxicology and Environmental Safety 72(2), 372-381.

Hédouin, L., Gomez Batista, M., Metian, M., Buschiazzo, E., Warnau M., 2010. Metal and metalloid bioconcentration capacity of two tropical bivalves for monitoring the impact of land-based mining activities in the New Caledonia lagoon. Marine Pollution Bulletin 61(7-12), 554-567.

Hédouin, L., Metian, M., Gates, R.D., 2011a. Ecotoxicological approach for assessing the contamination of a Hawaiian coral reef ecosystem (Honolua Bay, Maui) by metals and a metalloid. Marine Environmental Research 71(3), 149-161.

Hédouin, L., Pringault, O., Bustamante, P., Fichez, R., Warnau, M., 2011b. Transplantation experiments for the validation of two tropical marine bivalves as bioindicators of mining contamination in the New Caledonian lagoon. Water Research 45(2), 483-496.

JECFA (Joint Expert Committee on Food Additives), 2006. JECFA Evaluations e Cadmium. TRS 930JECFA 64/26.

Kulbicki, M., Bozec, Y.-M., Labrosse, P., Letourneur, Y., Mou-Tham, G., Wantiez, L., 2005. Diet composition of carnivorous fishes from coral reef lagoons of New Caledonia. Aquatic Living Resources 18, 231-250.

Le, X.C., Cullen, W.R., Reimer, K.J., 1994. Human urinary arsenic excretion after one-time ingestion of seaweed, crab and shrimp. Clinical Chemistry 40, 617-624.

Luoma, S.N., Hogstrand, C., Bell, R.A., Bielmyer, G.K., Galvez, F., LeBlanc, G.A., Lee, B.-G., Purcell, T.W., Santore, R.C., Santschi, P.H., Shaw, J.R., 2002. Biological processes, in: Andren, A.W., Bober, T.W. (Eds), Silver in the environment: transport, fate and effects. Society of Environment Toxicology and Chemistry (SETAC), Pensacola, pp. 65-96.

Meador, J.P., Ernest, D.W., Kagley, A., 2004. Bioaccumulation of arsenic in marine fish and invertebrates from Alaska and California. Archives of Environmental Contamination and Toxicology $47,223-233$.

Meador, J.P., Robisch, P.A., Clark, R.C.Jr., Ernest, D.W., 1998. Elements in fish and sediment from the Pacific Coast of the United States: Results from the national benthic surveillance project. Marine Pollution Bulletin 37(1-2), 56-66. 
Metian, M., Bustamante, P., Hédouin, L., Warnau, M., 2008a. Accumulation of nine metals and one metalloid in the tropical scallop Comptopallium radula from coral reefs in New Caledonia. Environmental Pollution 152, 543-552.

Metian, M., Giron, E., Borne, V., Hédouin, L., Teyssié, J.L., Warnau, W., 2008b. The brown alga Lobophora variegata, a bioindicator species for surveying metal contamination in tropical marine environments. Journal of Experimental Marine Biology and Ecology 362: 49-54

$2008 b$,

Metian, M., Hédouin, L., Lacoue-Labarthe, T., Eltayeb, M.M., Teyssié, J.-L., Mugnier, C., Warnau, M., 2010. Metal and metalloid bioaccumulation in the Pacific blue shrimp Litopenaeus stylirostris (Stimpson) from New Caledonia: laboratory and field studies. Marine Pollution Bulletin 61(7-12), 576-584.

Metian, M., Warnau, M., 2008. The tropical brown alga Lobophora variegata (Lamouroux) Womersley: a prospective bioindicator for $\mathrm{Ag}$ contamination in tropical coastal waters. Bulletin of Environmental Contamination and Toxicology 81, 455-458.

Monniot, F., Martoja, R., Monniot, C., 1994. Cellular sites of iron and nickel accumulation in ascidians related to the naturally and anthropic enriched New Caledonian environment. Annales de l'Institut Oceanographique 70(2), 205-216.

Moore, M.M., Harrington-Brock, K., Doerr, C.L., 1994. Genotoxicity of arsenic and its methylated metabolites. Environmental Geochemistry and Health16, 191-198.

Neff, J.M., 2002. Bioaccumulation in marine organisms: effect of contaminants from oil well produced water, Elsevier, Oxford.

Pernice, M., Boucher, J., Boucher-Rodoni, R., Joannot, P., Bustamante, P., 2009. Comparative bioaccumulation of trace elements between Nautilus pompilius and N. macromphalus (Cephalopoda: Nautiloidea) from Vanuatu and New Caledonia. Ecotoxicology and Environmental Safety 72(2), 365371.

Phillips, D.J.H., Rainbow, P.S., 1994. Biomonitoring of Trace Aquatic Contaminants Environemental series. 2nd edn. Chapman and Hall, London, UK.

Schafer, H.A., Hershelman, G.P., Young, D.R., Mearns, A.J., 1982. Contaminants in ocean food webs, in: Bascom, W. (Ed.), Coastal Water Research Project. Biennial Report for the Years 1981-1982. Southern California Coastal Water Research Project, Long Beach, pp. 17-28.

St. John, J., 1999. Ontogenetic changes in the diet of the coral reef grouper Plectropomus leopardus (Serranidae): patterns in taxa, size and habitat of prey. Marine Ecology Progress Series 180, 233-246.

Tao, S., Bolger, M., 1998. Dietary arsenic intakes in the United States: FDA Total Diet Study, September 1991-December 1996. Food Additives and Contaminants 16, 465-472.

Ting, R.Y., Vega, V.R., 1967. The nature of the distribution of trace elements in longnose anchovy (Anchoa lamprotaenia Hildebrand), Atlantic thread herring (Opisthonema oglinum LaSueur) and alga 
(Udotea flabellum Lamouroux), in: Nelson, D.J., Evans, F.C. (Eds), Symposium on radioecology, USAEC CONF-670503, Ann Arbor, pp. 527-534.

Young, D.R., Mearns, A.J., 1979. Pollutant flow through food webs, in: Bascom, W. (Ed.), Coastal Water Research Project. Annual Report for the Year 1978. Southern California Coastal Water Research Project, El Segundo, pp. 185-202

Young, D.R., Mearns, A.J., Jan, T.-K., Heesen, T.C., Moore, M.D., Eganhouse, R.P., Hershelman, G.P., Gossett, R.W., 1980. Trophic structure and pollutant concentrations in marine ecosystems of southern California. CalCOFI Report 21, 197-206.

Wang, W.-X., 2002. Interactions of trace metals and different marine food chains. Marine Ecology Progress Series 243, 295-309.

WHO (World Health Organization), 1989. Environmental Health Criteria 18 - Arsenic. World Health Organization, Geneva.

WHO, 2003. Joint FAO/WHO Expert Committee on Food Additives and Contaminants, Sixty-first

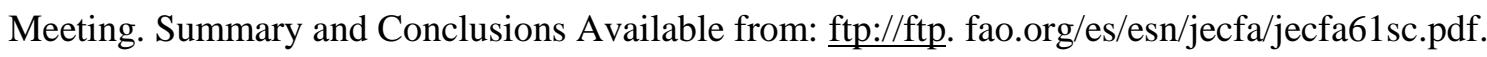

Willis, J.N., Sunda, W.G., 1984. Relative contributions of food and water in the accumulation of zinc by two species of marine fish. Marine Biology 80, 273-279.

$\mathrm{Xu}$, Y., Wang, W.-X., 2002. Exposure and potential food chain transfer factor of Cd., Se and Zn in marine fish Lutjanus argentimaculatus. Marine Ecology Progress Series 238, 173-186.

Zeller, D.C., 1997. Home range and activity patterns of the coral trout Plectropomus leopardus (Serranidae). Marine Ecology Progress Series 154, 65-77.

Zhang, L., Wang, W.-X., 2006. Significance of subcellular metal distribution in prey in influencing the trophic transfer of metals in a marine fish. Limnology and Oceanography 51(5), 2008-2017. 
Table 1: Characteristics of the fish collected in the New Caledonia lagoon.

\begin{tabular}{|c|c|c|c|c|c|c|}
\hline Family and species & $N$ & $\begin{array}{c}\text { Length }(\mathbf{m m}) \\
\text { Mean } \pm \text { SD (Range) }\end{array}$ & $\begin{array}{c}\text { Wet weight (g) } \\
\text { Mean } \pm \text { SD (Range) }\end{array}$ & Sampling site(s) (date*) & Trophic group & Life style \\
\hline \multicolumn{7}{|l|}{ Acanthuridae } \\
\hline \multicolumn{7}{|l|}{ Haemulidae } \\
\hline Two-striped sweetlips (Plectorhinchus albovittatus) & 1 & 405 & 1300 & Ouano Bay & Predator (invertebrates) & Neritic \\
\hline Harlequin sweetlips $(P$. chaetodonoides $)$ & 1 & 351 & 900 & Grande Rade & Predator (invertebrates and small fish) & Neritic \\
\hline Lemon sweetlips (P. flavomaculatus) & 1 & 485 & 1600 & Grande Rade & Predator (crustaceans and small fish) & Neritic \\
\hline Painted sweetlips (Diagramma pictum) & 1 & 451 & 1160 & Ouano Bay (O) & Predator (invertebrates and small fish) & Neritic \\
\hline \multicolumn{7}{|l|}{ Kyphosidae } \\
\hline \multicolumn{7}{|l|}{ Labridae } \\
\hline Golden-spot hogfish (Bodianus perditio) & 1 & 343 & 800 & Grande Rade & Predator (invertebrates) & Neritic \\
\hline Floral wrasse (Cheilinus chlorourus) & 1 & 290 & 450 & Koutio Bay & Predator (invertebrates) & Neritic \\
\hline \multicolumn{7}{|l|}{ Lethrinidae } \\
\hline Grass emperor (Lethrinus laticaudis) & 3 & $266 \pm 11(256-277)$ & $376 \pm 45(331-420)$ & Southern Lagoon & Predator (crustaceans and small fish) & Neritic \\
\hline Humpnose big-eye bream (Monotaxis grandoculis) & 2 & $261 \pm 7(256-266)$ & $420 \pm 21(405-434)$ & Southern Lagoon & Predator (invertebrates) & Neritic \\
\hline \multicolumn{7}{|l|}{ Lutjanidae } \\
\hline Mangrove red snapper (Lutjanus argentimaculatus) & 5 & $449 \pm 63(348-510)$ & $1345 \pm 494(625-1900)$ & $\begin{array}{l}\text { Grande Rade (M\&O), } \\
\text { Ouno Bay, Maa Bay }\end{array}$ & Predator (crustaceans and small fish) & Neritic \\
\hline Onespot snapper (L. monostigma) & 2 & $249 \pm 37(223-275)$ & $475 \pm 177(350-600)$ & Ouano Bay, Maa Bay & Predator (crustaceans and small fish) & Neritic \\
\hline \multicolumn{7}{|l|}{ Platycephalidae } \\
\hline Crocodile fish (Cymbacephalus beauforti) & 2 & $510 \pm 99(440-580)$ & $1425 \pm 530(1050-1800)$ & Prony $(\mathrm{O})$ & Predator (small fish) & Benthic \\
\hline \multicolumn{7}{|l|}{ Priacanthidae } \\
\hline Moontail bullseye (Priacanthus hamrur) & 7 & $307 \pm 21(285-340)$ & $454 \pm 96(360-600)$ & Ouano Bay & Predator (invertebrates and small fish) & Neritic \\
\hline \multicolumn{7}{|l|}{ Scaridae } \\
\hline Blue-barred parrotfish (Scarus ghobban) & 1 & 247 & 245 & Koutio Bay & Grazer / Scavenger & Neritic \\
\hline Blunt-head parrotfish (S. microrhinos) & 1 & 508 & 3000 & Ouano Bay & Grazer / Scavenger & Neritic \\
\hline Rivulated parrotfish (S. rivulatus) & 1 & 355 & 900 & Ouano Bay & Grazer / Scavenger & Neritic \\
\hline Yellowband parrotfish (S. schlegeli) & 1 & 249 & 400 & Ouano Bay & Grazer / Scavenger & Neritic \\
\hline \multicolumn{7}{|l|}{ Serranidae } \\
\hline Leopard coral grouper (Plectropomus leopardus) & 21 & $413 \pm 110(265-615)$ & $1294 \pm 1051(300-3800)$ & $\begin{array}{l}\text { Grande Rade (M\&O), } \\
\text { Koutio Bay, Ouano Bay } \\
\text { (M\&O), Maa Bay, Sainte } \\
\text { Marie Bay, Prony (O) }\end{array}$ & Predator (small fish) & Neritic \\
\hline Highfin grouper (Epinephelus maculates) & 1 & 340 & 480 & Ouano Bay & Predator (invertebrates and small fish) & Neritic \\
\hline Whitespotted grouper (Epinephelus coeruleopunctatus) & 1 & 470 & 1500 & Prony $(\mathrm{O})$ & Predator (crustaceans and small fish) & Neritic \\
\hline \multicolumn{7}{|l|}{ Sparidae } \\
\hline Goldsilk seabream (Acanthopagrus berda) & 2 & $275 \pm 5(271-278)$ & $550 \pm 71(500-600)$ & Ouano Bay, Maa Bay & Predator (invertebrates and small fish) & Neritic \\
\hline
\end{tabular}




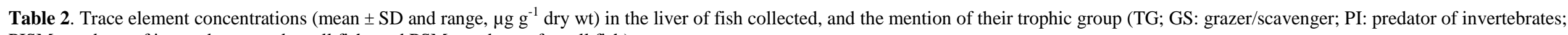
PISM: predator of invertebrates and small fish; and PSM: predator of small fish).

\begin{tabular}{|c|c|c|c|c|c|c|c|c|c|c|c|c|c|c|c|c|}
\hline Scientific name and location & TG & $\mathbf{N}$ & $\mathrm{Ag}$ & As & Cd & Co & $\mathrm{Cr}$ & $\mathrm{Cu}$ & $\mathrm{Fe}$ & $\mathrm{Hg}$ & Mn & $\mathrm{Ni}$ & $\mathbf{P b}$ & Se & $\mathbf{v}$ & $\mathbf{Z n}$ \\
\hline \multirow[t]{2}{*}{ Kyphosus vaigiensis } & GS & 5 & $0.05 \pm 0.02$ & $<8.15$ & $8.12 \pm 2.38$ & $1.55 \pm 0.70$ & $1.10 \pm 0.38$ & $23.2 \pm 12.5$ & $910 \pm 390$ & $0.25 \pm 0.03$ & $2.29 \pm 0.77$ & $1.60 \pm 0.08$ & $<0.08$ & $<16.3$ & $<1.63$ & $97.6 \pm 12.3$ \\
\hline & & & $0.02-0.08$ & - & $5.92-11.4$ & $0.66-2.28$ & $0.81-1.56$ & $10.0-40.0$ & $260-1280$ & $0.21-0.29$ & $1.45-3.33$ & $1.47-1.67$ & - & - & - & $76.0-107$ \\
\hline Naso unicornis & GS & 1 & 0.07 & 10.2 & 8.92 & 5.62 & 0.82 & 9.44 & 4618 & 0.31 & 3.92 & $<1.64$ & $<0.08$ & $<16.4$ & 7.22 & 110 \\
\hline Scarus ghobban & GS & 1 & 0.04 & $<9.41$ & 0.06 & 1.24 & 0.94 & 2.00 & 249 & 0.06 & 2.63 & $<1.88$ & 0.14 & $<18.8$ & $<1.88$ & 20.0 \\
\hline S. microrhinos & GS & 1 & 0.03 & $<7.74$ & 0.88 & 1.34 & $<0.77$ & 1.00 & 241 & 0.03 & 0.93 & $<1.55$ & $<0.08$ & $<15.5$ & $<1.55$ & 23.0 \\
\hline S. rivulatus & GS & 1 & 0.04 & $<9.88$ & 2.64 & 0.53 & 0.99 & 2.00 & 544 & 0.04 & 1.14 & $<1.98$ & $<0.08$ & $<19.8$ & 1.98 & 22.0 \\
\hline S. schlegeli & GS & 1 & 0.04 & $<8.77$ & 0.63 & 0.24 & 0.88 & 4.00 & 254 & 0.04 & 1.45 & $<1.75$ & $<0.08$ & $<17.5$ & $<1.75$ & 46.0 \\
\hline Bodianus perditio & PI & 1 & 0.05 & 43.8 & 0.25 & 0.80 & 0.83 & 8.78 & 1600 & 5.04 & 2.42 & $<1.65$ & 0.21 & $<16.5$ & $<1.65$ & 63.0 \\
\hline Cheilinus chlorourus & PI & 1 & 1.96 & 10.4 & 3.39 & 6.25 & 0.80 & 53.0 & 7080 & 2.69 & 4.27 & 1.62 & 0.24 & 19.10 & 3.83 & 122 \\
\hline Monotaxis grandoculis & PI & 2 & $0.05-0.10$ & $10.0-17.0$ & $1.91-4.51$ & $0.42-0.46$ & $<0.80-0.84$ & $9.87-24.4$ & $1270-1300$ & $0.11-0.11$ & $2.95-3.06$ & $<1.60$ & $0.07-0.08$ & $16.8-17.3$ & $<1.60$ & $134-175$ \\
\hline Plectorhinchus albovittatus & PI & 1 & 0.04 & 13.4 & 0.35 & 0.78 & 0.82 & 17.0 & 1860 & 0.73 & 2.27 & $<1.64$ & 0.10 & $<16.4$ & $<1.64$ & 330 \\
\hline \multicolumn{17}{|l|}{ Acanthopagrus berda } \\
\hline Maa & PISM & 1 & 0.08 & $<7.42$ & 1.21 & 4.89 & $<0.74$ & 22.0 & 1120 & 0.48 & 7.02 & $<1.48$ & $<0.07$ & $<14.8$ & $<1.48$ & 131 \\
\hline Ouano & PISM & 1 & 0.14 & 17.9 & 5.13 & 0.71 & $<0.75$ & 174 & 1200 & 0.25 & 7.11 & $<1.51$ & 0.14 & $<15.1$ & 2.09 & 344 \\
\hline Diagramma pictum & PISM & 1 & 0.13 & 9.54 & 0.92 & 1.36 & $<0.65$ & 50.1 & 2340 & 0.28 & 3.81 & 3.20 & 0.49 & 17.7 & $<1.30$ & 199 \\
\hline E pinephelus maculates & PISM & 1 & 0.56 & $<8.15$ & 2.89 & 1.98 & 0.82 & 167 & 3530 & 1.00 & 5.46 & $<1.63$ & $<0.08$ & 21.3 & $<1.63$ & 1153 \\
\hline E. coeruleopunctatus & PISM & 1 & 0.54 & $<5.29$ & 0.18 & 0.42 & $<0.53$ & 55.7 & 2240 & 0.88 & 1.52 & $<1.06$ & $<0.05$ & $<10.6$ & $<1.06$ & 1034 \\
\hline \multirow[t]{2}{*}{ Lethrinus laticaudis } & PISM & 3 & $0.08 \pm 0.02$ & $16.7 \pm 5.75$ & $5.46 \pm 3.56$ & $0.50 \pm 0.14$ & $1.38 \pm 0.79$ & $26.1 \pm 8.59$ & $2130 \pm 760$ & $0.25 \pm 0.14$ & $3.75 \pm 0.59$ & 1.67 & $0.11 \pm 0.07$ & $17.1 \pm 1.25$ & 1.65 & $261 \pm 15.6$ \\
\hline & & & $0.06-0.11$ & $10.4-21.4$ & $3.33-9.57$ & $0.34-0.61$ & $<0.81-1.94$ & $17.0-34.0$ & $1270-2690$ & $0.15-0.41$ & $3.34-4.42$ & $<1.62-$ & $0.06-0.19$ & $16.2-18.5$ & - & $243-270$ \\
\hline \multicolumn{17}{|l|}{ Lutjanus argentimaculatus } \\
\hline Grande Rade & PISM & 2 & $0.60-3.32$ & $<6.82$ & $0.19-0.21$ & $0.61-2.51$ & $<0.68$ & $67.9-160$ & $1450-4110$ & $1.10-1.40$ & $3.23-5.97$ & $<1.36$ & $0.16-0.33$ & $<13.6$ & $<1.36-1.46$ & $349-648$ \\
\hline Maa & PISM & 1 & 0.03 & $<8.18$ & 0.06 & 6.68 & 0.82 & 28.0 & 4400 & 1.57 & 5.22 & $<1.63$ & 0.09 & $<16.3$ & 3.92 & 332 \\
\hline Ouano & PISM & 2 & $0.09-0.11$ & $<8.10$ & $1.47-1.77$ & $1.07-1.41$ & 0.81 & $17.7-40.3$ & $1520-3450$ & $0.42-0.43$ & $5.05-5.79$ & $<1.62$ & $<0.08$ & $<16.2$ & $1.93-4.83$ & $456-543$ \\
\hline \multicolumn{17}{|l|}{ L. monostigma } \\
\hline Maа & PISM & 1 & 0.03 & $<7.78$ & 5.94 & 6.22 & $<0.78$ & 14.0 & 8770 & 1.51 & 8.77 & 3.34 & 1.37 & $<15.6$ & 1.77 & 663 \\
\hline Ouano & PISM & 1 & 0.04 & $<7.74$ & 2.49 & 1.95 & $<0.79$ & 12.0 & 1910 & 0.63 & 5.20 & $<1.59$ & 0.26 & $<15.9$ & $<1.59$ & 214 \\
\hline Plectorhinchus chaetodonoides & PISM & 1 & 0.11 & 20.1 & 0.95 & 5.86 & 0.83 & 18.0 & 3660 & 1.72 & 8.30 & 5.02 & 1.68 & 18.7 & 1.72 & 156 \\
\hline P. flavomaculatus & PISM & 1 & 0.21 & 29.3 & 0.63 & 2.79 & $<0.70$ & 21.0 & 1930 & 1.61 & 3.48 & 4.17 & 1.82 & 20.8 & $<1.40$ & 109 \\
\hline \multirow[t]{2}{*}{ Priacanthus hamrur } & PISM & 7 & $0.05 \pm 0.02$ & $10.1 \pm 2.2$ & $6.20 \pm 5.36$ & $0.25 \pm 0.05$ & $2.06 \pm 1.79$ & $23.0 \pm 12.2$ & $1870 \pm 710$ & $0.38 \pm 0.26$ & $6.07 \pm 0.71$ & $1.79 \pm 0.45$ & $<0.08$ & 16.1 & $<1.61$ & $282 \pm 143$ \\
\hline & & & $0.03-0.08$ & $<7.93-11.7$ & $1.40-16.7$ & $0.17-0.31$ & $<0.79-5.33$ & $9.0-40.0$ & $960-2870$ & $0.15-0.76$ & $5.44-7.22$ & $1.59-2.79$ & - & $<16.1-16.1$ & - & $109-535$ \\
\hline \multirow{3}{*}{$\begin{array}{c}\text { Plectropomus leopardus } \\
\text { Grande Rade }(M)\end{array}$} & PSM & 2 & $0.17-0.18$ & $<6.01-11.5$ & $1.24-1.82$ & $0.36-040$ & $<0.55$ & $16.7-45.8$ & $3370-5640$ & $3.19-4.09$ & $1.31-2.55$ & $<1.20$ & $<0.06$ & $\begin{array}{l}<12.0 \\
\end{array}$ & $1.20-2.10$ & $48.0-71.0$ \\
\hline & PSM & 3 & $3.47 \pm 1.24$ & $<8.10$ & $0.24 \pm 0.01$ & $1.18 \pm 0.58$ & $0.81 \pm 0.00$ & $111 \pm 27.0$ & $2500 \pm 350$ & $5.25 \pm 0.73$ & $2.91 \pm 0.37$ & $<1.62$ & $0.24+0.05$ & $<16.2$ & $5.66+2.40$ & $393+167$ \\
\hline & & & $2.08-4.47$ & - & $0.24-0.25$ & $0.81-1.84$ & $<0.77-0.81$ & $80.0-128$ & $2130-2820$ & $4.68-6.07$ & $2.63-3.33$ & - & $0.20-0.29$ & -2 & $3.76-8.36$ & $282-585$ \\
\hline Grande Rade $(\mathrm{O})$ & PSM & 2 & $0.28-0.57$ & $<11.4$ & $0.07-0.12$ & $0.22-0.50$ & $<0.65$ & $63.1-69.2$ & $820-1730$ & $0.64-1.71$ & $4.69-5.66$ & $<2.29$ & $0.11-0.16$ & $<22.9$ & $<2.29$ & $126-63$ \\
\hline \multirow[t]{2}{*}{ Koutio } & PSM & 4 & $5.39 \pm 1.02$ & $<8.27$ & $0.10 \pm 0.02$ & $0.30 \pm 0.05$ & $0.83 \pm 0.01$ & $316 \pm 100$ & $2100 \pm 640$ & $0.33 \pm 0.06$ & $3.24 \pm 0.37$ & 2.80 & $0.10 \pm 0.02$ & $<16.5$ & $<1.65$ & $666 \pm 250$ \\
\hline & & & $3.87-6.05$ & 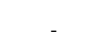 & $0.08-0.12$ & $0.24-0.36$ & $<0.53-0.83$ & $222-424$ & $1320-2780$ & $0.26-0.38$ & $2.74-3.62$ & $\begin{array}{l}<1.65- \\
2.80\end{array}$ & $0.08-0.12$ & & - & 498-1029 \\
\hline \multirow[t]{2}{*}{ Maa } & PSM & 4 & $1.86 \pm 0.63$ & $<8.23$ & $0.54 \pm 0.19$ & $0.73 \pm 0.33$ & $0.82 \pm 0.01$ & $467 \pm 155$ & $4090 \pm 2070$ & $0.43 \pm 0.19$ & $3.30 \pm 0.38$ & $<1.65$ & $<0.08$ & $<16.5$ & 4.00 & $735 \pm 147$ \\
\hline & & & $1.11-2.57$ & - & $0.36-0.77$ & $0.48-1.18$ & $<0.74-0.82$ & $322-642$ & $2660-7140$ & $0.26-0.71$ & $2.83-3.69$ & - & - & - & $<1.48-4.00$ & $539-883$ \\
\hline Ouano (M) & PSM & 2 & $0.19-0.25$ & $<8.20$ & $3.30-4.98$ & $0.42-1.20$ & $<0.76-0.82$ & $38.0-135$ & $3100-7840$ & $3.06-6.44$ & $3.54-5.74$ & $<1.64$ & $0.08-0.13$ & $<16.4$ & $2.99-5.47$ & $866-1052$ \\
\hline Ouano $(O)$ & PSM & 2 & $0.09-0.14$ & $<5.97$ & $0.31-0.75$ & $0.13-0.28$ & $<0.60$ & $22.1-55.2$ & $1200-2650$ & $0.27-0.41$ & $1.57-1.85$ & $<1.19$ & $<0.06$ & $<11.9$ & $<1.19$ & 656-702 \\
\hline Prony & PSM & 1 & 0.16 & $<5.46$ & 0.33 & 0.32 & $<0.55$ & 90.9 & 1120 & 0.09 & 3.57 & $<1.09$ & $<0.05$ & $<10.9$ & $<1.09$ & 678 \\
\hline Sainte Marie & PSM & 3 & $5.36 \pm 1.04$ & $<8.07$ & $0.15 \pm 0.09$ & $0.70 \pm 0.26$ & $0.92 \pm 0.22$ & $366 \pm 207$ & $3730 \pm 2290$ & $1.02 \pm 0.43$ & $3.16 \pm 1.19$ & $<1.61$ & $0.09 \pm 0.02$ & $<16.1$ & $2.53 \pm 1.58$ & $1079 \pm 505$ \\
\hline & & & $4.61-6.55$ & & $0.09-0.26$ & $0.50-0.99$ & $0.78-1.18$ & $185-591$ & $2090-6350$ & $0.53-1.34$ & $2.22-4.50$ & & $0.08-0.12$ & & $1.56-4.35$ & $760-1662$ \\
\hline
\end{tabular}


Table 3. Trace element concentrations (mean $\pm \mathrm{SD}$ and range, $\mu \mathrm{g} \mathrm{g}^{-1}$ dry wt) in the muscle of fish collected, and the mention of their trophic group (TG; GS: grazer/scavenger; PI: predator of invertebrates; PISM: predator of invertebrates and small fish; and PSM: predator of small fish).

\begin{tabular}{|c|c|c|c|c|c|c|c|c|c|c|}
\hline Scientific name and location & TG & $\mathbf{N}$ & As & Co & $\mathrm{Cr}$ & $\mathrm{Cu}$ & $\mathbf{F e}$ & Mn & $\mathbf{P b}$ & $\mathbf{Z n}$ \\
\hline Kyphosus vaigiensis & GS & 5 & $<8.26$ & $\begin{array}{l}0.20 \pm 0.07 \\
0.11-0.30\end{array}$ & $\begin{array}{c}<0.83 \\
-\end{array}$ & $\begin{array}{c}<0.83 \\
-\end{array}$ & $\begin{array}{l}8.69 \pm 1.06 \\
760-102\end{array}$ & $<0.83$ & $\begin{array}{c}<0.08 \\
-\end{array}$ & $\begin{array}{l}24.1 \pm 8.51 \\
173-382\end{array}$ \\
\hline Naso unicornis & GS & 1 & $<7.99$ & 0.13 & $<0.80$ & $<0.80$ & 10.0 & $<0.80$ & $<0.08$ & 8.59 \\
\hline Scarus ghobban & GS & 1 & $<8.16$ & 0.30 & $<0.82$ & $<0.82$ & 10.7 & $<0.82$ & $<0.08$ & 9.83 \\
\hline S. microrhinos & GS & 1 & $<8.18$ & 0.26 & $<0.82$ & $<0.82$ & 7.88 & 1.06 & $<0.08$ & 10.4 \\
\hline S. rivulatus & GS & 1 & $<8.17$ & 0.12 & $<0.82$ & $<0.82$ & 11.7 & $<0.82$ & $<0.08$ & 9.29 \\
\hline S. schlegeli & GS & 1 & $<8.03$ & 0.07 & $<0.80$ & $<0.80$ & 13.6 & $<0.80$ & $<0.08$ & 11.7 \\
\hline Bodianus perditio & PI & 1 & 18.3 & 0.04 & $<0.82$ & $<0.82$ & 13.4 & $<0.82$ & $<0.08$ & 16.6 \\
\hline Cheilinus chlorourus & PI & 1 & $<7.85$ & 0.07 & $<0.78$ & $<0.78$ & 9.70 & $<0.78$ & $<0.08$ & 12.2 \\
\hline Monotaxis grandoculis & PI & 2 & $<8.12$ & $<0.03$ & $<0.81$ & $<0.81$ & $6.60-7.14$ & $<0.81$ & $<0.08$ & $10.5-12.1$ \\
\hline Plectorhinchus albovittatus & PI & 1 & 25.4 & $<0.03$ & $<0.83$ & $<0.83$ & 15.5 & $<0.83$ & 0.10 & 12.7 \\
\hline \multicolumn{11}{|l|}{ Acanthopagrus berda } \\
\hline Maa & PISM & 1 & 10.4 & 0.05 & $<0.78$ & $<0.78$ & 8.16 & $<0.78$ & $<0.08$ & 14.9 \\
\hline Ouano & PISM & 1 & 21.0 & $<0.03$ & $<0.80$ & $<0.80$ & 8.06 & $<0.80$ & 0.14 & 14.0 \\
\hline Diagramma pictum & PISM & 1 & 6.83 & 0.02 & $<0.61$ & 0.64 & 12.7 & $<0.61$ & $<0.06$ & 12.8 \\
\hline Epinephelus coeruleopunctatus & PISM & 1 & 8.38 & $<0.02$ & $<0.59$ & $<0.59$ & 6.19 & $<0.59$ & $<0.06$ & 13.2 \\
\hline E. maculates & PISM & 1 & $<7.99$ & $<0.03$ & $<0.80$ & $<0.80$ & 22.7 & $<0.80$ & $<0.08$ & 13.7 \\
\hline \multirow{2}{*}{ Lethrinus laticaudis } & PISM & 3 & $13.7 \pm 7.57$ & $<0.03$ & $<0.79$ & $<0.79$ & $9.19 \pm 1.42$ & $<0.79$ & $<0.08$ & $11.8 \pm 0.23$ \\
\hline & & & $<7.87-19.1$ & - & - & - & $7.56-10.1$ & - & - & $11.6-12.0$ \\
\hline \multicolumn{11}{|l|}{ Lutjanus argentimaculatus } \\
\hline Grande Rade & PISM & 2 & $<8.19$ & $<0.02-0.03$ & $<0.82$ & $<0.82$ & $8.87-9.72$ & $<0.82$ & $<0.08-0.11$ & $12.0-12.8$ \\
\hline Maa & PISM & 1 & $<8.25$ & $<0.03$ & $<0.82$ & $<0.82$ & 15.7 & $<0.82$ & 0.09 & 12.2 \\
\hline Ouano & PISM & 2 & $<8.05$ & $<0.03$ & $<0.81$ & $<0.81$ & $11.2-11.8$ & $<0.81$ & $<0.08$ & $11.6-12.5$ \\
\hline \multicolumn{11}{|l|}{ L. monostigma } \\
\hline Maa & PISM & 1 & $<7.60$ & 0.35 & $<0.76$ & $<0.76$ & 14.5 & $<0.76$ & $<0.08$ & 10.3 \\
\hline Ouano & PISM & 1 & $<8.08$ & 0.08 & $<0.81$ & $<0.81$ & 11.8 & $<0.81$ & $<0.08$ & 10.5 \\
\hline Plectorhinchus chaetodonoides & PISM & 1 & 24.5 & 0.12 & $<0.78$ & 1.51 & 22.6 & $<0.78$ & $<0.08$ & 15.3 \\
\hline P. flavomaculatus & PISM & 1 & 38.5 & 0.10 & $<0.82$ & 1.08 & 17.0 & $<0.82$ & $<0.08$ & 16.2 \\
\hline \multirow[t]{2}{*}{ Priacanthus hamrur } & PISM & 7 & $9.47 \pm 1.47$ & $<0.03$ & 1.39 & $<0.83$ & $10.4 \pm 3.56$ & $<0.83$ & 0.09 & $282 \pm 143$ \\
\hline & & & $<7.85-10.7$ & - & $<0.70-1.39$ & - & $7.82-16.9$ & - & $<0.07-0.09$ & $109-535$ \\
\hline $\begin{array}{l}\text { Cymbacephalus beauforti } \\
\text { Plectropomus leopardus }\end{array}$ & PSM & 2 & $<6.01-7.77$ & $<0.02$ & $<0.60$ & $<0.53-0.64$ & $7.01-7.60$ & $<0.60$ & $<0.05-0.07$ & $11.8-14.11$ \\
\hline \multirow{2}{*}{ Grande Rade (March) } & PSM & 3 & $<8.02$ & $<0.03$ & $<0.80$ & $<0.80$ & $8.48 \pm 1.59$ & $<0.80$ & $<0.08$ & $13.0 \pm 1.96$ \\
\hline & & & - & - & - & - & $6.89-10.1$ & - & - & $11.2-15.1$ \\
\hline Grande Rade (October) & & 2 & $<5.89$ & $<0.02$ & $<0.59$ & $<0.59-0.71$ & $8.00-18.3$ & $<0.59$ & $0.12-0.15$ & $12.5-15.6$ \\
\hline \multirow[t]{2}{*}{ Koutio } & & 4 & $<8.25$ & $<0.03$ & $<0.83$ & $<0.83$ & $9.73 \pm 1.41$ & $<0.83$ & $<0.08$ & $11.3 \pm 0.63$ \\
\hline & & & - & - & - & - & $8.41-11.5$ & - & - & $11.3-12.7$ \\
\hline \multirow[t]{2}{*}{$M a a$} & & 4 & $<8.26$ & $<0.03$ & $<0.83$ & $<0.83$ & $11.1 \pm 5.39$ & $<0.83$ & $<0.08$ & $11.4 \pm 0.35$ \\
\hline & & & - & - & - & - & $8.23-19.2$ & - & - & $10.9-11.7$ \\
\hline Ouano (fMarch) & & 2 & $<8.18$ & $<0.03$ & $<0.82$ & $<0.82$ & $6.98-14.8$ & $<0.82$ & $<0.08$ & $12.9-13.0$ \\
\hline Ouano (October) & & 2 & $<5.49$ & $<0.02-0.02$ & $<0.55-0.88$ & $<0.55 \& 0.46$ & $6.76-37.1$ & $<0.55$ & $<0.08$ & $14.7-16.4$ \\
\hline Prony & & 1 & $<5.90$ & $<0.02$ & $<0.59$ & $<0.59$ & 8.51 & $<0.59$ & $<0.06$ & 10.9 \\
\hline \multirow[t]{2}{*}{ Sainte Marie } & & 3 & $<7.73$ & $<0.03$ & $<0.77$ & $<0.77$ & $6.43 \pm 1.55$ & $<0.77$ & $<0.08$ & $12.8 \pm 1.33$ \\
\hline & & & - & - & - & - & $5.38-8.21$ & - & - & $11.5-14.1$ \\
\hline
\end{tabular}


Table 4. Liver Co, Cr, Mn, Ni, Se, and V concentrations (mean \pm SD or range; $\mu \mathrm{g} \mathrm{g}^{-1} \mathrm{dwt}$ ) in fish from various geographical areas.

\begin{tabular}{|c|c|c|c|c|c|c|c|c|}
\hline Species & Location & Co & $\mathrm{Cr}$ & Mn & $\mathbf{N i}$ & Se & $\mathbf{V}$ & References \\
\hline Parupeneus multifasciatus & Maui, Hawaii, USA & $1.98 \pm 0.79$ & $1.44 \pm 1.05$ & $7.42 \pm 1.76$ & $0.53 \pm 0.38$ & nd & $5.11 \pm 2.38$ & Hédouin et al., 2011a \\
\hline 15 species & Townsville Coastal Waters, Australia & nd & $<0.6-2.8$ & nd & $<0.2-7.4$ & nd & nd & Burden-Jones et al., 1975 \\
\hline 32 species & Guam harbours, Guam & nd & $<0.15-1.58$ & nd & $<0.16-<1.35$ & nd & nd & Denton et al., 2006 \\
\hline 50 species & Great Barrier Reef, Australia & nd & nd & nd & all $<0.5$ & nd & nd & Denton and Burdon-Jones, 1986 \\
\hline 22 species & Lagoon of New Caledonia & $0.13-6.67$ & $0.78-5.33$ & $0.93-8.77$ & $<1.09-5.02$ & $16.2-21.3$ & $1.20-8.36$ & Present study \\
\hline Compendium data* & - & $0.05-4.8$ & $<0.04-3.6$ & up to 1,1 & up to 7.6 & up to 6.7 & 0,024 & Eisler, 2010 \\
\hline
\end{tabular}

nd $=$ no data. $/ *$ since the water contents of fish livers vary widely only values reported in dry weight were included. 


\section{Caption to figures}

Figure 1. Map of the sampling sites along the South coast of New Caledonia and in the vicinity of Noumea City (its position is indicated by a black star).

Figure 2. Projection of variables and individuals on the first two components resulting from the principal component analysis (PCA). A) Correlation bi-plot showing the distribution of the variables. The length of the line for a variable shows how well it is represented by the two-dimensional approximation, and reflects its contribution to the first two principal components. Horizontal axis: principal component 1 (24\%); vertical axis: principal component 2 (20\%). Variables pointing in the same direction display a high positive correlation. Variables pointing in the opposite direction have a high negative correlation. Variables with an angle of $90^{\circ}$ have a correlation close to 0 . B) Projection of individuals on the correlation bi-plot with eigenvalue of the first two components. C) Grouping of individuals by sampling sites. D) Grouping of individuals by trophic groups.

Figure 3. Comparison of trace element concentrations in the liver of leopard coral grouper Plectropomus leopardus among sampling sites. Tukey multiple comparison tests were performed after one-way ANOVA or ANCOVA (Weight as covariable for $\mathrm{Co}, \mathrm{Hg}, \mathrm{V}$ and Length for $\mathrm{Cu}$ ). Mean concentrations are ranked from the left to the right by increasing order. Underlines (_) indicate locations among which concentrations are not significantly different $(\alpha=0.05)$.

Sampling locations are: Ouano Bay (Ouano), Grande Rade (GR), Maa Bay (Maa), Koutio Bay (Koutio) and Sainte-Marie Bay (SM).

Significant differences: $*$ for $\mathrm{p}<0.05 ; * *$ for $\mathrm{p}<0.01 ; * * *$ for $\mathrm{p}<0.001$

Figure 4. Global comparison of metal concentrations ( $\mu \mathrm{g} \mathrm{g}^{-1}$ dry wt; except for $\mathrm{Hg}$ : ng $\mathrm{g}^{-1}$ dry wt) in the liver of fish from New Caledonia according to their trophic group. GS: grazer/scavenger $(n=10)$; PI: predator of invertebrates $(n=5)$; PISM: predator of invertebrates and small fish $(\mathrm{n}=23)$; and PSM: predator of small fish $(\mathrm{n}=24)$. Significant differences: $*$ for $\mathrm{p}<0.05 ; * *$ for $\mathrm{p}<0.01$; $* * *$ for $\mathrm{p}<0.001$ 


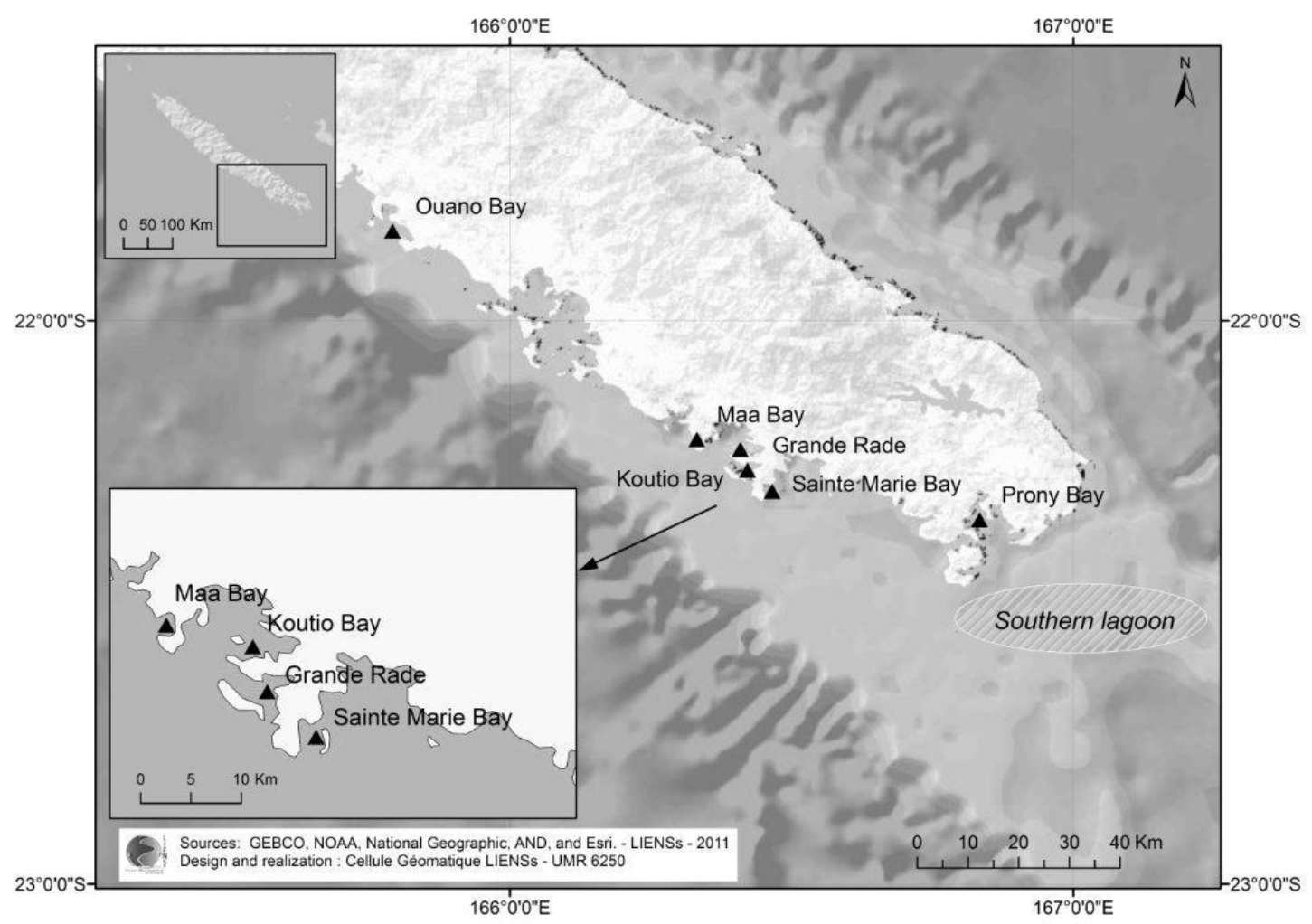

Figure 1 


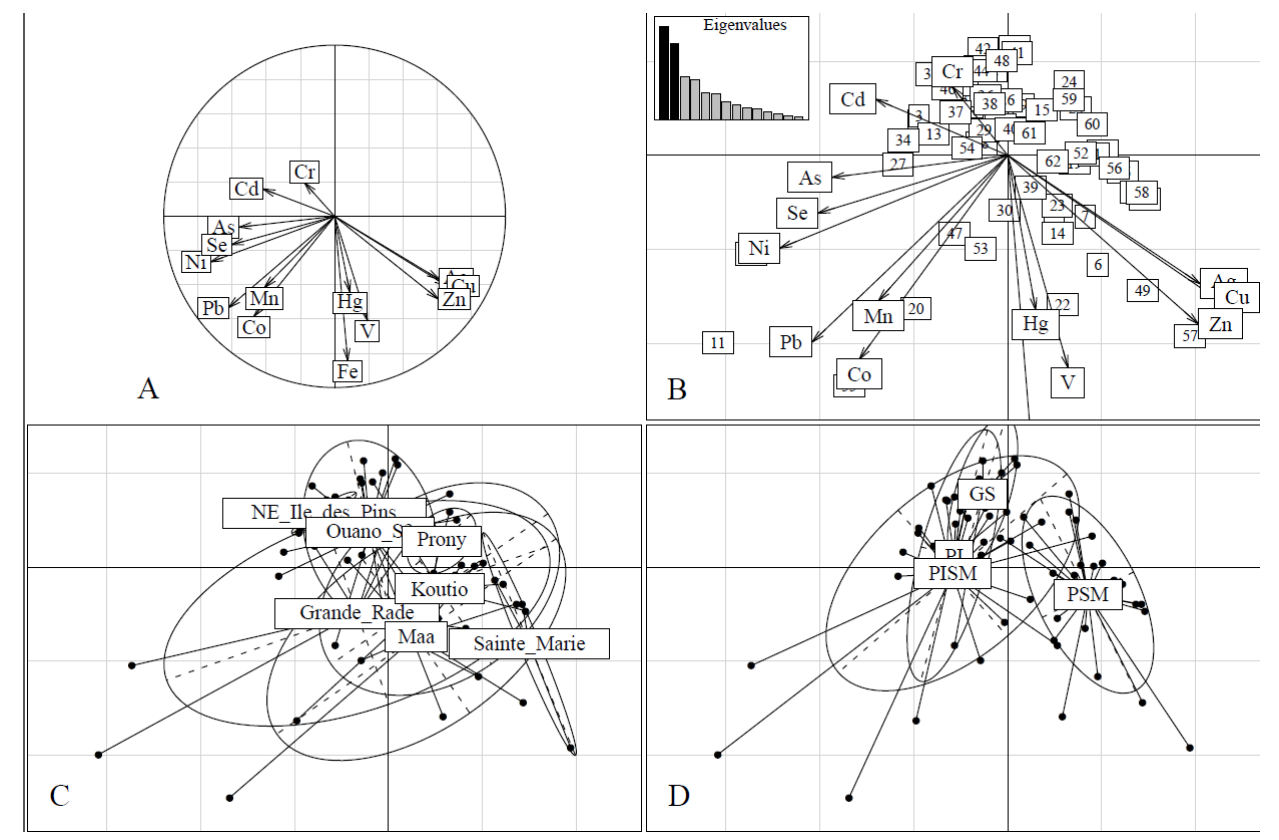

Figure 2 


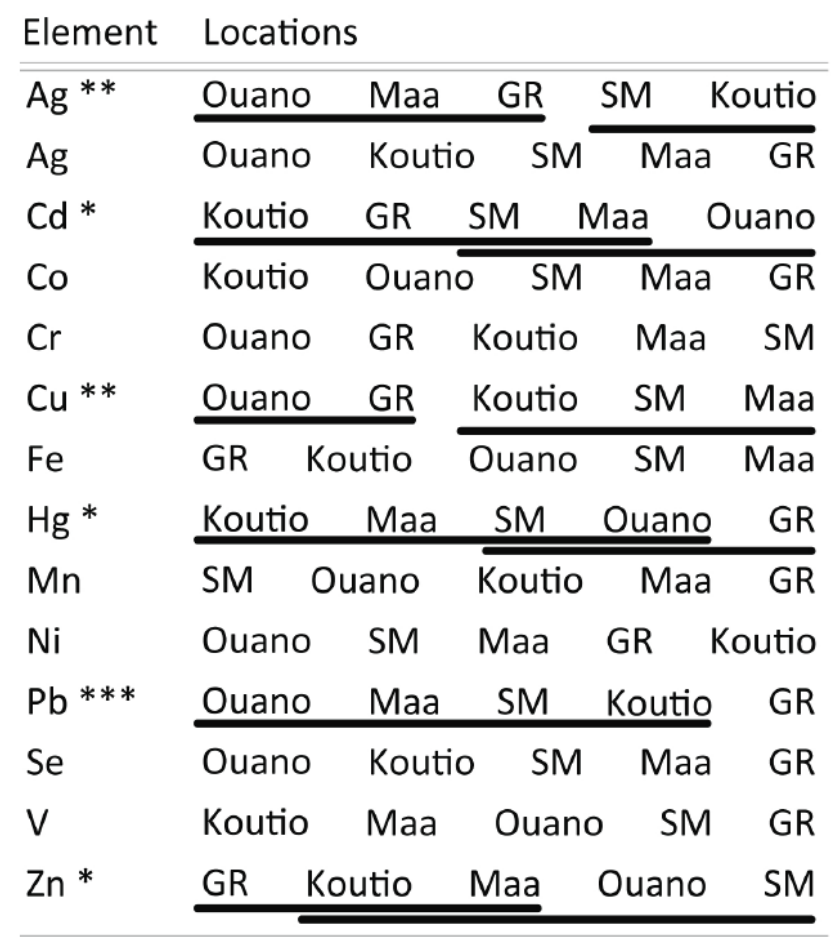

Figure 3 


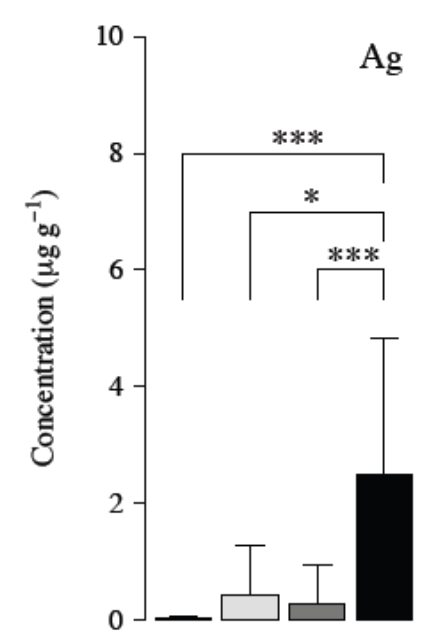

GS PI PISM PSM

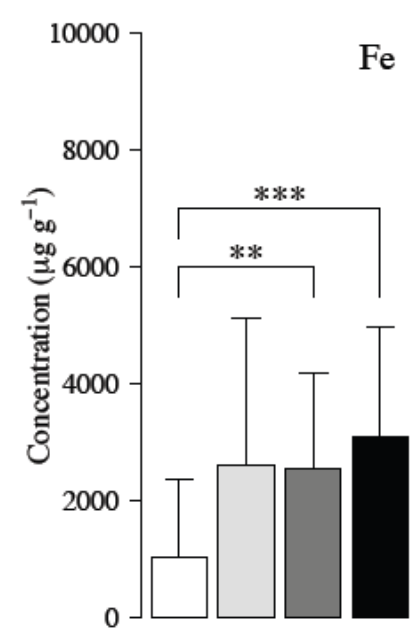

GS PI PISM PSM

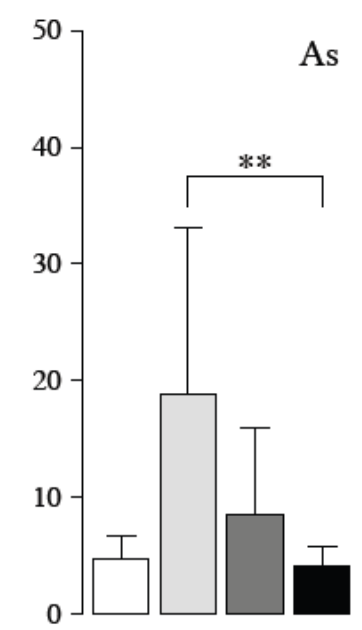

GS PI PISM PSM

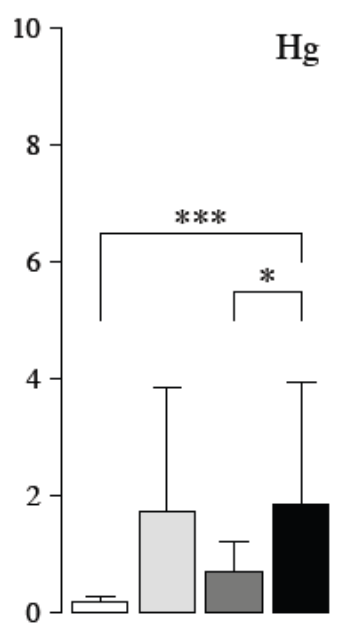

GS PI PISM PSM

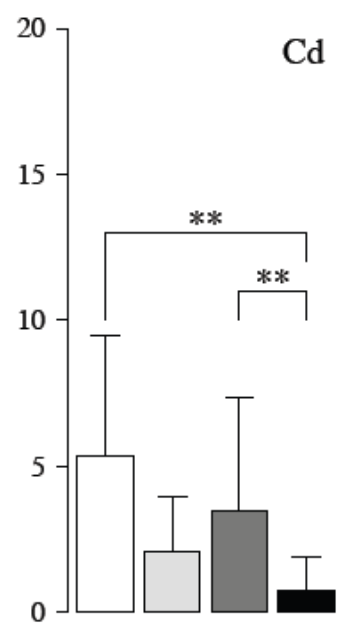

GS PI PISM PSM

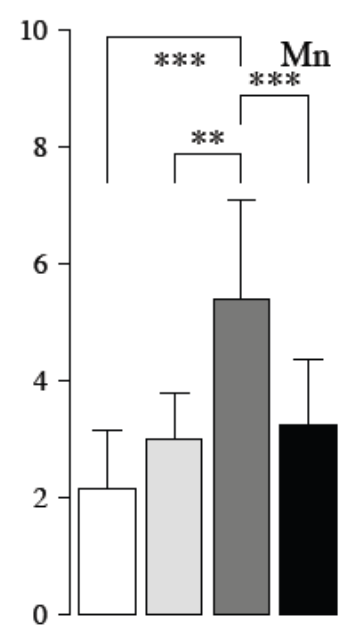

GS PI PISM PSM

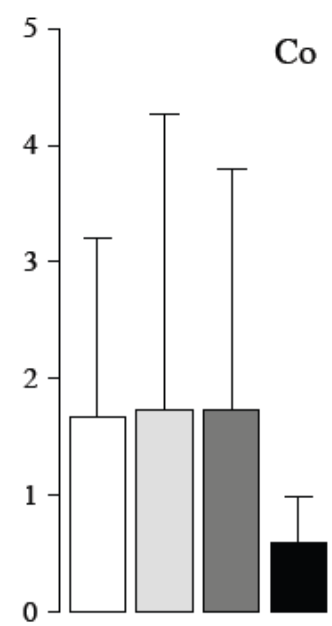

GS PI PISM PSM

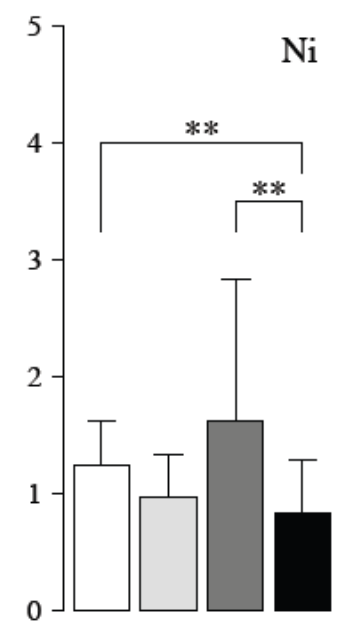

GS PI PISM PSM

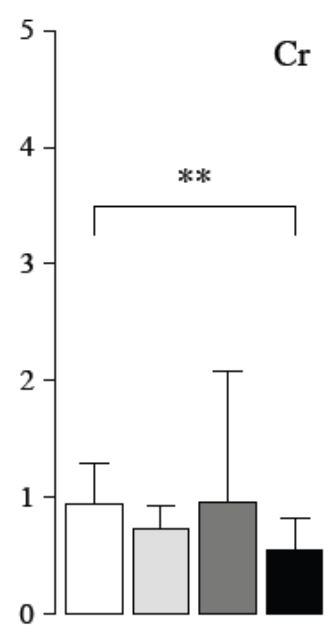

GS PI PISM PSM

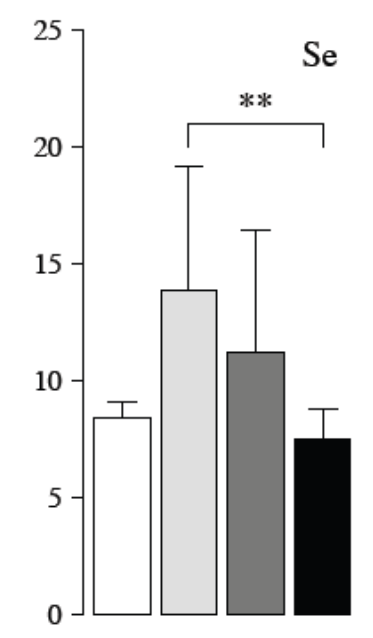

GS PI PISM PSM

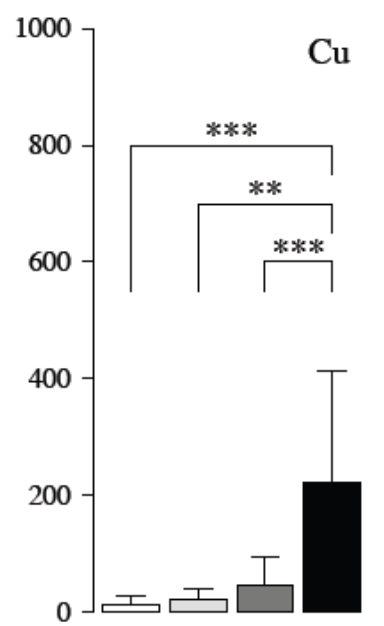

GS PI PISM PSM

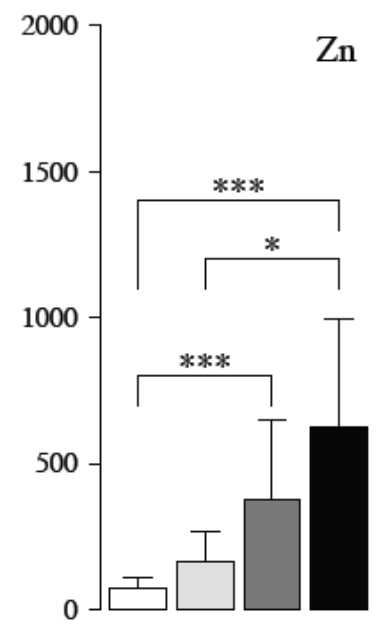

GS PI PISM PSM

Figure 4 